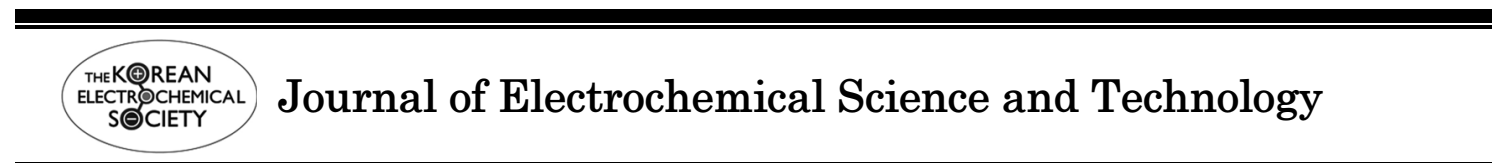

\title{
Electrochemistry of Gallium
}

\author{
Yonghwa Chung and Chi-Woo Lee ${ }^{\dagger}$ \\ Department of Advanced Materials Chemistry, Korea University, 2511 Sejongro, Sejong 339-700, Republic of Korea
}

\begin{abstract}
:
Gallium is an important element in the production of a variety of compound semiconductors for optoelectronic devices. Gallium has a low melting point and is easily oxidized to give oxides of different compositions that depend on the conditions of solutions containing Ga. Gallium electrode reaction is highly irreversible in acidic media at the dropping mercury electrode. The passive film on a gallium surface is formed during anodic oxidation of gallium metal in alkaline media. Besides, some results in published reports have not been consistent and reproducible. An increase in the demand of intermetallic compounds and semiconductors containing gallium gives rise to studies on electrosynthesis of them and an increase of gallium concentration in the environment with various application of gallium causes the development of electroanalysis tools of Ga. It is required to understand the electrochemistry of $\mathrm{Ga}$ and to predict the electrochemical behavior of $\mathrm{Ga}$ to meet these needs. Any review papers related to the electrochemistry of gallium have not been published since 1978, when the review on the subject was published by Popova et al. In this study, the redox behavior, anodic oxidation, and electrodeposition of gallium, and trace determination of gallium by stripping voltammetries will be reviewed.
\end{abstract}

Keywords: Gallium, Reduction, Oxidation, Electrodeposition, Stripping voltammetry

Received March 7, 2013 : Accepted March 27, 2013

\section{Introduction}

Gallium is a rare metal which has a low melting point of $29.75^{\circ} \mathrm{C}$. Gallium is distributed in the earth's crust with an average abundance of $16 \mathrm{ppm} .{ }^{1)}$ Gallium occurs as gallium(III) compounds in small quantities in germanite, zinc ores, aluminum-bearing minerals and coals. Most gallium is produced as a byproduct of the production of zinc and aluminum. Gallium metal is obtained from electrolytes containing gallium through electrolysis. ${ }^{2)}$

Gallium is mostly used as a component of semiconductors for microelectronics and thin-film photovoltaic cells. Semiconducting materials containing gallium such as $\mathrm{GaAs}, \mathrm{GaN}$, InGaN and $\mathrm{Cu}(\mathrm{InGa}) \mathrm{Se}_{2}$ are used in microwave intergrated circuits, laser

${ }^{\dagger}$ Corresponding author. Tel.: +82-44-860-1333

E-mail address: cwlee@korea.ac.kr diodes, light-emitting diodes (LEDs), and solar cells. ${ }^{1,3)}$ It is well known that small amounts of gallium, when alloyed with aluminum cause activation of aluminum surface. The activation of aluminum by gallium enables the uses of aluminum as an anode material in primary batteries or sacrificial anodes. ${ }^{4}$

Trace amounts of gallium exist in human body via natural water, vegetables and fruits, however its physiological function has not been known. Ga(III) can be easily taken up by the blood as the transferrin-gallium complex because of the similarity between $\mathrm{Ga}(\mathrm{III})$ and $\mathrm{Fe}(\mathrm{III})$. It is not considered to be hazardous with touching pure gallium. For intravenous injection of gallium lactate, about $40 \mathrm{mg} / \mathrm{kg}$ in rats or rabbits was lethal. Some gallium compounds exhibited antiinflammatory, immunosuppressive activity of human disease, and their potential to function as antimicrobial agents against some pathogens. Therefore the threat posed by continuous exposure to $\mathrm{Ga}$ (III) should not be 
ignored. $^{2,5)}$ The level of gallium in the environment around industrial area is beginning to rise, due to the various uses of gallium and gallium compounds. Thus the determination of gallium trace in the environment or biological samples has been studied. ${ }^{6)}$ The voltammetric determinations have been applied to the analysis of gallium. ${ }^{7)}$

The review published by Popova et al. ${ }^{8)}$ has shown that the electrochemical behaviors of gallium vary widely. The stable oxidation state of gallium is +3 , corresponding to solvated $\mathrm{Ga}^{3+}$ in acidic solution and gallate in alkaline solution. Depending on the $\mathrm{pH}$ value, various trivalent gallium ions such as $\mathrm{Ga}^{3+}$, $\mathrm{Ga}(\mathrm{OH})^{2+}, \mathrm{GaO}^{+}, \mathrm{GaO}_{2}{ }^{-}, \mathrm{H}_{2} \mathrm{GaO}_{3}{ }^{-}, \mathrm{Ga}(\mathrm{OH})_{4}{ }^{-}$, $\mathrm{HGaO}_{3}{ }^{2-}$, and $\mathrm{GaO}_{3}{ }^{3-}$ may exist in aqueous solution. The Pourbaix diagrams (Fig. 1) ${ }^{9}$ ) show equilibrium states between possible gallium species for the $\mathrm{Ga}(\mathrm{III})$ in aqueous systems and the theoretical conditions of corrosion and passivation of $\mathrm{Ga}$.

Corbett et al ${ }^{10)}$ showed the existence of monovalent gallium in alkaline solutions as the formation of $\mathrm{Ga}(\mathrm{I})\left[\mathrm{Ga}(\mathrm{III}) \mathrm{I}_{4}\right]$. Sipos et al. ${ }^{11)}$ investigated highly concentrated alkaline gallate solution with $0.23 \mathrm{M} \leq$ $\mathrm{C}_{\mathrm{Ga}(\mathrm{III})} \leq 2.32 \mathrm{M}$ and $1 \mathrm{M} \leq \mathrm{C}_{\mathrm{NaOH}} \leq 15 \mathrm{M}$ by Raman and ${ }^{71} \mathrm{Ga}$-NMR spectroscopy. They could identify only one species, the tetrahedral hydroxocomplex, $\mathrm{Ga}(\mathrm{OH})_{4}^{-}$, present in the alkaline gallate solutions through both the Raman and ${ }^{71} \mathrm{Ga}-\mathrm{NMR}$ spectra. Anders and Plambeck ${ }^{12)}$ observed the oxidation of $\mathrm{Ga}$ metal to $\mathrm{Ga}(\mathrm{I})$ and the oxidation and reduction of $\mathrm{Ga}(\mathrm{I}) / \mathrm{Ga}(\mathrm{III})$ in $\mathrm{AlCl}_{3}-\mathrm{NaCl}-\mathrm{KCl}$ melt via Nernst plot and voltammetry.

Richards and Boyer ${ }^{13)}$ measured a single electrode potential of gallium for the first time which reached a maximum about $-0.3 \mathrm{~V}$ (using a calomel half-cell as a reference) in a $0.1 \mathrm{~N}$ gallium solution. Saltman and Nachtrieb used the cell $\mathrm{Ga}_{\text {sol }} / \mathrm{GaCl}_{3}, \mathrm{HCl} / \mathrm{Pt}\left(\mathrm{H}_{2}\right)$ to obtain $\mathrm{E}_{\mathrm{Ga}(\mathrm{S})}^{\mathrm{o}}=-0.53 \mathrm{~V}(\mathrm{NHE})$ at $28^{\circ} \mathrm{C} .{ }^{14)}$

Gallium electrode reaction (GER) is highly irreversible in $\mathrm{HClO}_{4}$ media at the dropping mercury electrode (DME), however the appearance of a room temperature reversible GER is synergetically controlled by the presence of $\mathrm{SCN}^{-}$in the cell of a state of high ionic strength $(\mathrm{J}){ }^{15,16)}$

Liquid gallium can be used as dropping electrode. The overpotential measurements pertaining to the hydrogen electrode reaction (HER) on liquid gallium has been conducted in acidic and alkaline media and in the presence of alkali metal. ${ }^{17-19)}$ Liquid gallium's double-layer structure in aqueous solutions has been investigated via analysis of electrocapillary curves, ${ }^{20}$ ) differential capacity, ${ }^{21)}$ and dropping electrode charging current measurement techniques. The structure of the electrical double layer on solid gallium had been investigated using differential capacity ${ }^{22)}$ and 'estance method' invented Gokhshtein. ${ }^{23)}$ The absolute values of the capacity of solid gallium are larger than liquid gallium due to surface roughness.

Studies on the passivation and dissolution of liquid and solid gallium were performed. Wolf had shown that the electrochemical behavior of gallium was influenced by oxide film which presumably consisted of


Fig. 1. Potential vs. $\mathrm{pH}$ equilibrium diagram at $25^{\circ} \mathrm{C}$ (a) for the gallium-water system and (b) theoretical conditions for corrosion, immunity, and passivation of gallium [modified from ref. 9]. 
$\mathrm{Ga}_{2} \mathrm{O}_{3} \cdot{ }^{24)}$ During the anodic dissolution of gallium in acid solutions an oxide film of constant thickness is formed which permits penetration of $\mathrm{Ga}^{3+}$. In neutral salt solutions, passivation of solid gallium apparently occurs more easily than for the liquid metal and it depends as well upon temperature and $\mathrm{pH} .{ }^{25}$ Solid gallium was not passivated in $1.0 \mathrm{M} \mathrm{HCl}$, but at lesser acid concentrations both the solid and liquid metal were affected. The liquid gallium was less inhibited than for the solid. ${ }^{26)}$ In the range of applied potential from +0.2 to $+2.0 \mathrm{~V}$, liquid gallium in $0.5 \mathrm{M} \mathrm{H}_{2} \mathrm{SO}_{4}$ was covered with a passivating film mainly consisting of basic gallium sulfate. ${ }^{27)}$ Faizullin et al. suggested that in the first stage of anodic dissolution, a primary film was formed from an electrochemical reaction of $\mathrm{Ga}$ with $\mathrm{OH}$, or with water molecules. ${ }^{28)}$ They assumed three stages of oxidation in $\mathrm{pH} 9.2$ buffer solution: 1) formation of $\mathrm{GaOOH}$ film with adsorbed $\mathrm{H}_{2} \mathrm{O}$, 2) formation of $\mathrm{GaOOH}$ and its chemical dissolution accompanied by generation of gallate ions, and 3) abrupt potential increase induced by formation of a passivating film. ${ }^{29)}$ The polarization on the solid gallium surface is more reproducible and higher than on the liquid gallium due to different mechanical properties of the passivating surface film. ${ }^{30)}$ For the formation of $\mathrm{Ga}_{2} \mathrm{O}_{3}$ on solid gallium and liquid gallium, the oxidation on liquid gallium occurs without overpotential, while on solid gallium the reaction occurs at a 70 $\mathrm{mV}$ polarization. ${ }^{31)}$ Popova et al. ${ }^{32)}$ reported that the solid gallium electrode has a higher reduction potential of oxide than liquid gallium.

The dissolution of liquid gallium in $0.1 \mathrm{M} \mathrm{NaOH}$ solution yielded $\mathrm{Ga}(\mathrm{OH})_{6}{ }^{3-}$ and the possibility of participation of $\mathrm{Ga}(\mathrm{I})$ and $\mathrm{Ga}(\mathrm{II})$ as soluble intermediates was observed during dissolution of $\mathrm{Ga}^{33)}$ Hurlen et $a .^{34)}$ also found the formation of unstable Ga species with lower oxidation states in $\mathrm{H}_{2} \mathrm{SO}_{4}$, or $\mathrm{NaOH}$ solution which eventually oxidize to Ga(III). However, in a $\mathrm{HCl}$ solution a steady state corresponding to $\mathrm{Ga}(\mathrm{II})$ existed presumably due to stabilization via chloride complexation. ${ }^{35)} \mathrm{Ga}(\mathrm{III})$ is dominant in electrochemical dissolution of $\mathrm{Ga}$ in alkaline media with the overall rate governed by transfer of the third electron to form $\mathrm{Ga}(\mathrm{OH})_{4}{ }^{-}$or its gallate equivalent. ${ }^{36}$ )

Electrochemical processes on Ga have been investigated mainly using the dropping gallium electrode. Tangential motions of the gallium drop surface caused by capillary "out flow" were investigated by Bagotskaya and Genkina. ${ }^{37)}$ Cadmium, zinc, indium, ${ }^{38)}$ and nickel ${ }^{39)}$ waves on the dropping gallium electrode were observed. Bagotskaya and Durmanov ${ }^{40)}$ determined $E_{1 / 2}$ for the reduction of certain halo derivatives of aromatic and aliphatic compound on the dropping $\mathrm{Ga}$ electrode in aqueous and aqueous-alcohol $\mathrm{HCl}$ solution.

Bockris and Enyo ${ }^{41)}$ suggested the mechanism of reduction of trivalent gallium on liquid and solid gallium electrodes in an alkaline solution involved the elementary reaction of bivalent and monovalent gallium ions as following:

$\mathrm{HGaO}_{2}^{-}+\mathrm{GaO}^{-}+\mathrm{H}_{2} \mathrm{O} \rightarrow \mathrm{Ga}+\mathrm{H}_{2} \mathrm{GaO}_{3}^{-}+\mathrm{OH}^{-}$

However, Corbett ${ }^{35)}$ disagreed with Bockris's mechanism on the grounds that bivalent gallium ions were unstable in alkaline solutions and the principal reaction of monovalent gallium with water in aqueous acid or base was the formation of hydrogen and Ga(III). Kochegarov and Lomakina ${ }^{42)}$ found that during gallium electroplating, the hydrogen evolution reaction by employing high gallate concentration can be mitigated.

Gallium readily forms intermetallic alloy compound with other metallic elements. Vasil'eva and Zebreva ${ }^{43}$ showed the formation of Tl-Cu-Ga alloy by simultaneous deposition of $\mathrm{Tl}$ and $\mathrm{Cu}$ on the surface of solid gallium.

In this work, we will review redox behaviors of gallium on several electrodes including mercury electrode in solution, kinetic parameters with respect to the electrode reaction of gallium, anodic oxidation of solid and liquid gallium, and electrodeposition of gallium and gallium alloys. The level of gallium in environment is starting to increase with increase in application of gallium to micro electronics and photovoltaic cells, etc. Therefore trace determination of gallium has become important. Here we'll review studies on anodic and cathodic stripping voltammetries. This follows our previous reviews on electrochemistry of indium $^{44)}$ and selenium ${ }^{45)}$ relevant to copper-indiumgalium-selenium solar cell materials.

\section{Electrochemistry of Gallium}

\subsection{Redox behavior of gallium in aqueous solution}

Lots of results of pholarographic experiments on gallium electrode reaction (GER) indicated that GER is highly irreversible in various electrolyte solutions. ${ }^{8)}$ 
However, reversible gallium reduction was attained by the addition of $\mathrm{N}_{3}^{-46)}$ or halide ${ }^{47)}$ as well as $\mathrm{SCN}^{-15,16)}$ to the solution and by elevated temperature.

Iwasinska et al. ${ }^{48)}$ measured the formal potential of $\mathrm{Ga}(\mathrm{III}) / \mathrm{Ga}(0)$ in a $4 \mathrm{M} \mathrm{NaClO}_{4}$ solution with a $\mathrm{pH}$ of 2.0 at $25^{\circ} \mathrm{C}$. The potential value measured using gallium amalgam was $-0.731 \mathrm{~V}$ vs. SCE. The authors observed that the increase in $\mathrm{SCN}^{-}$concentration caused a pronounced increase in cathodic current and suggested that the actual catalytic species responsible for reduction of $\mathrm{Ga}$ (III) might be adsorbed reduced hydrogen that was catalyzed by $\mathrm{SCN}^{-}$. Moorhead and Frame $^{49)}$ reported that reversible $\mathrm{Ga}(\mathrm{III})$ reduction might involve the formation of $\mathrm{Ga}(\mathrm{SCN})_{4}{ }^{-}$in a solution containing $6 \mathrm{M} \mathrm{NaClO}_{4}, 0.1 \mathrm{M} \mathrm{NaSCN}$, and 2 $\mathrm{mM} \mathrm{Ga}(\mathrm{III})$ at $30^{\circ} \mathrm{C}$ and $\mathrm{pH} 1$. However, this suggestion disagreed with Iwasinska's result that the bulk species in $\mathrm{NaClO}_{4}-\mathrm{NaSCN}$ media was a complex with stoichiometric ratio of $2: 1$ of $\mathrm{SCN}^{-}$and $\mathrm{Ga}(\mathrm{III})$. Sharma et al. ${ }^{50)}$ investigated cyclic voltammetry (CV) of $\mathrm{Ga}$ (III) in sodium perchlorate solutions with and without sodium thiocyanate, at static mercury drop electrode (SMDE). The CV of Ga(III) (Fig. 2(a)) showed high irreversibility of the electro-redox process of $\mathrm{Ga}(\mathrm{III}) / \mathrm{Ga}$ at $\mathrm{SMDE}$ in a $\mathrm{NaClO}_{4}$ solution. However the $\mathrm{CV}$ behavior of $\mathrm{Ga}(\mathrm{III})$ in $4 \mathrm{M} \mathrm{NaClO}_{4}$ solution containing $0.5 \mathrm{M} \mathrm{NaSCN}$ approached closer to reversible and the positive shift of about $480 \mathrm{mV}$ in cathodic peak potential was observed on adding

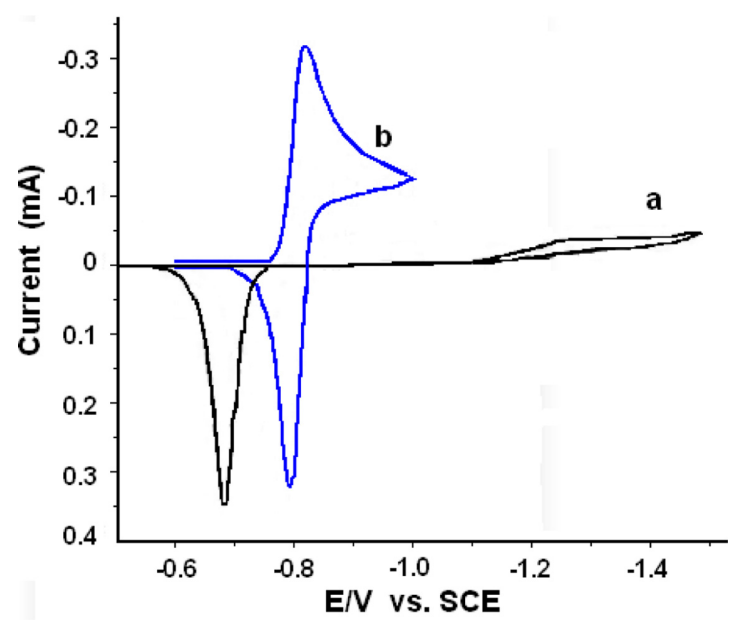

Fig. 2. Cyclic voltammograms of $1 \mathrm{mM} \mathrm{Ga(III)}$ at SMDE (a) in $4 \mathrm{M} \mathrm{NaClO}_{4}$ at a scan rate of $20 \mathrm{mV} / \mathrm{s}$, and (b) in $4 \mathrm{M}$ $\mathrm{NaClO}_{4}$ containing $0.5 \mathrm{M} \mathrm{NaSCN}$ at a scan rate $200 \mathrm{mV} / \mathrm{s}$ [modified from Figs. 1 and 3 of ref. 50]. sodium thiocyanate as shown in Fig. 2(b).

Moorhead and Robison ${ }^{51)}$ reported that azide anion promoted the reversible reduction of $\mathrm{Ga}^{3+}$ ions unassisted by high ionic strength or elevated temperature from a differential pulse (DP) voltammetric study of aquogallium (III) in $0.58 \mathrm{M}$ azide $\left(\mathrm{N}_{3}^{-}\right)$media at $\mathrm{pH} 4$. According to their observations the azide-induced reaction did not require the high salt conditions or elevated temperatures unlike when thiocyanate was used. The authors assumed that azide nucleophile bound rather firmly to (very likely polynuclear) $\mathrm{Ga}$ (III) based on changes in $\mathrm{E}_{\mathrm{p}}$ with $\mathrm{pH}$ and azide, the failure of oxide to precipitates prior to $\mathrm{pH} 4$, and sigmoidal increase of $i_{p}$ with added azide. Sharma and Gupta ${ }^{52)}$ investigated the formation and electrochemistry of the complexes through the interaction of $\mathrm{Ga}(\mathrm{III})$ and $\mathrm{L}$ glutamine in the presence of $0.1 \mathrm{M} \mathrm{KNO}_{3}$ and $0.002 \%$ Triton-x-100 at pH 3.5 using a polarographic method. $\mathrm{Ga}(\mathrm{III})$ and L-glutamine under this condition formed $1: 1,1: 2$, and $1: 3$ gallium(III)- L-glutamine complexes. The Ga(III)-L-glutamine reduction wave at DME was well-defined, diffusion controlled but the nature of the electrode reduction was irreversible in all concentrations of the ligand at 30 and $40^{\circ} \mathrm{C}$. The number of electrons (n) involved in the reduction was determined to be 3 for $\mathrm{Ga}(\mathrm{III})$.

Kozin and Gaidin ${ }^{53)}$ studied the mechanism of gallium discharge and ionization on a liquid gallium electrode in a fluoride-alkaline electrolyte. The authors used $\mathrm{GaF}_{3}$ and $\mathrm{KF}$ as activating agents to raise the electrochemical reversibility of the anodic and cathodic reactions of gallium in alkaline electrolytes. As the potential of the gallium electrode shifted to more electropositive values, the electrode process of gallium ionization gave rise to intermediates, $\mathrm{Ga}^{+}$ ions. After the equilibrium concentration of $\mathrm{Ga}^{+}$was reached, $\mathrm{Ga}^{+}$ions underwent disproportionation (DPP) in accordance with the Eq. (2):

$$
3 \mathrm{Ga}^{+} \rightleftharpoons 2 \mathrm{Ga}^{0}+\mathrm{Ga}^{3+}
$$

As the anodic polarization increases, negatively charged $\mathrm{OH}^{-}$and $\mathrm{F}^{-}$ions are adsorbed and consumed in steadily increasing amounts. In the end, well soluble fluorohydroxo complexes of gallium were formed as following:

$$
\mathrm{Ga}^{3+}+3 \mathrm{OH}^{-}+\mathrm{KF} \rightleftharpoons\left[\mathrm{Ga}(\mathrm{OH})_{3} \mathrm{~F}\right] \mathrm{K}
$$

In the cathodic polarization of the gallium electrode, the mixed complex $\left(\left[\mathrm{Ga}(\mathrm{OH})_{3} \mathrm{~F}\right]^{-}\right)$also dissociated to 
give positively charged ions of fluoride and hydroxide complexes $\left([\mathrm{GaF}]^{2+},[\mathrm{Ga}(\mathrm{OH}) \mathrm{F}]^{+},[\mathrm{Ga}(\mathrm{OH})]^{2+}\right)$. The contact of gallium ions of the highest valence with metallic gallium could yield gallium(I) monohydroxides, monofluorides and/or their mixed complex through the reproportionation (RPP) reactions (Eqs. 4-6):

$$
\begin{aligned}
& \mathrm{Ga}^{3+}+2 \mathrm{Ga}^{0} \rightleftharpoons 3 \mathrm{Ga}^{+} \\
& \mathrm{GaX}_{3}+2 \mathrm{Ga}^{0} \rightleftharpoons 3 \mathrm{GaX} \\
& {\left[\mathrm{GaX}_{4}\right]^{-}+2 \mathrm{Ga}^{0} \rightleftharpoons \mathrm{GaX}_{2}^{-}+2 \mathrm{GaX}}
\end{aligned}
$$

The presence of fluoride ions in the solution resulted in that the stability of $\mathrm{Ga}(\mathrm{I})$ ions $\left(\mathrm{GaF},[\mathrm{Ga}(\mathrm{OH}) \mathrm{F}]^{-}\right)$ increased and binuclear mixed complexes, $[\mathrm{Ga}(\mathrm{I})$ $\left.\mathrm{Ga}(\mathrm{III})(\mathrm{OH})_{3} \mathrm{~F}\right]$ were formed.

$\mathrm{Ga}^{3+}$ ions with $\mathrm{SCN}^{-}$or $\mathrm{N}_{3}^{-}$formed $\mathrm{Ga}(\mathrm{III})$-complexes in acidic solutions and the reduction of the complexes became closer to an reversible one. The addition of $\mathrm{F}^{-}$in an alkaline media raised the reversibility of the redox reaction of gallium.

\subsection{Redox behavior of gallium in non-aqueous solution}

In aqueous acidic solution, thiocyanate ion with high ionic strength or azide ion had proved to be effective in achieving a reversible reduction of gallium (III). Cofre et al. ${ }^{54)}$ chose 2,2'-bipyridine (DIPY) as a ligand to obtain electrocatalytic reduction of $\mathrm{Ga}(\mathrm{III})$ in non-aqueous solution. They studied the electrochemistry of Ga(III) to Ga metal at a static mercury drop electrode in the presence of DIPY in dimethylsulfoxide (DMSO) and acetonitrile $(\mathrm{MeCN})$ and the effect of free proton (from $\mathrm{HClO}_{4}$ ) on the electrocatalytic reduction. Electron bridging through adsorbed DIPY would facilitate the $\mathrm{Ga}(\mathrm{III})$ reduction to Ga metal. A gallium metal deposit was obtained by reduction of the complex compound, $\mathrm{Ga}(\mathrm{DIPY})_{3}\left(\mathrm{ClO}_{4}\right)_{3}$ in DMSO, whereas lower valence Ga-DIPY species were obtained in $\mathrm{MeCN}$. It was shown that the metal deposition was restricted by the interference of free protons. Chen et $a l .{ }^{55)}$ investigated the electrochemistry of $\mathrm{Ga}(\mathrm{I})$ at tungsten and glassy carbon in the Lewis acidic molten salt in a vacuum atmosphere. The authors identified the redox reactions of $\mathrm{Ga}(\mathrm{III}) / \mathrm{Ga}(\mathrm{I})$ and $\mathrm{Ga}(\mathrm{I}) / \mathrm{Ga}(0)$ couples on a tungsten electrode in 60.0/40.0 mol \% aluminum chloride $\left(\mathrm{AlCl}_{3}\right)$-1-methyl-3-ethylimidazolium chloride (MEIC) molten salt. In the cyclic voltammogram measured at glassy carbon, the cathodic wave for the reduction of $\mathrm{Ga}(\mathrm{III})$ to $\mathrm{Ga}(\mathrm{I})$ was not seen

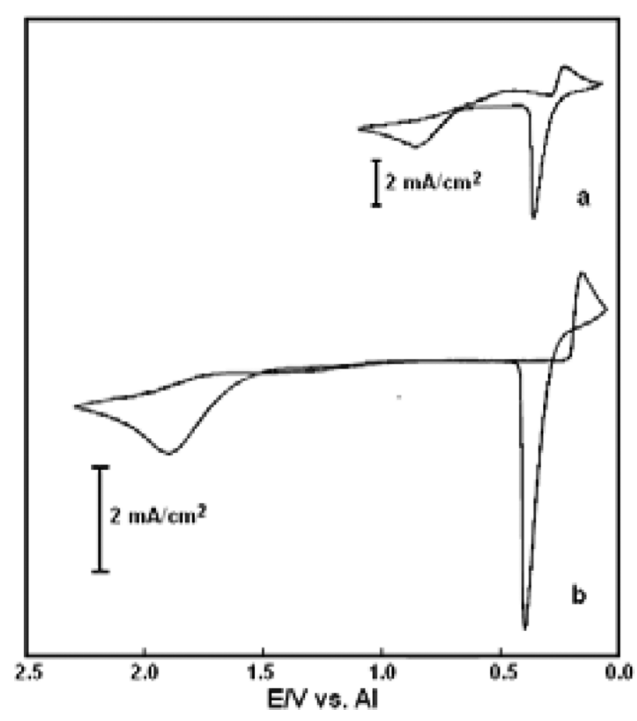

Fig. 3. Cyclic voltammograms of $21.4 \mathrm{mM} \mathrm{Ga(I)} \mathrm{at} \mathrm{a}$ tungsten electrode (a) and $21.1 \mathrm{mM} \mathrm{Ga(I)}$ at a glassy carbon electrode (b) in 60.0/40.0 mol \% $\mathrm{AlCl}_{3}$-MEIC at $30^{\circ} \mathrm{C}$ [modified from Figs. 3 and 5 of ref. 55].

as seen in Fig. 3(b). The authors obtained the formal potentials of the $\mathrm{Ga}(\mathrm{III}) / \mathrm{Ga}(\mathrm{I})$ and $\mathrm{Ga}(\mathrm{I}) / \mathrm{Ga}(0)$ couples on tungsten electrodes in the $\mathrm{AlCl}_{3}$-MEIC molten salt $(40: 60 \mathrm{~mol} \%)$ at $30^{\circ} \mathrm{C}$, that were 0.655 and $0.437 \mathrm{~V}$ (vs. Al) respectively. Smolenski et al ${ }^{56)}$ measured cyclic voltammograms after introducing gallium trichloride into the molten salt system of $\left[\mathrm{C}_{6} \mathrm{H}_{11} \mathrm{~N}_{2}\right]\left[\mathrm{N}\left(\mathrm{SO}_{2} \mathrm{CF}_{3}\right)_{2}\right]\left(\right.$ EtMeIm- $\mathrm{Tf}_{2} \mathrm{~N}$, 1-ethyl-3methyl imidazolium bis(trifluoromethyl sulfonyl) imide). On tungsten electrode cathodic and anodic peaks appeared at potentials of $-1.7 \mathrm{~V}$ and $0.2 \mathrm{~V}$ (vs. $\mathrm{W}$ reference electrode), respectively. Analysis of IR-

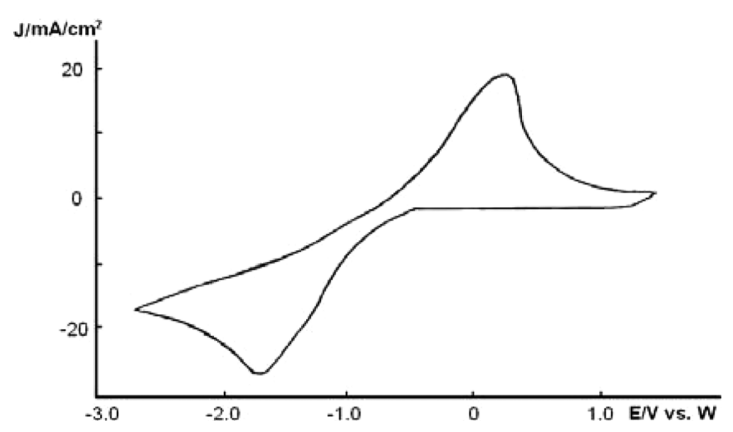

Fig. 4. Cyclic voltammogram of $\mathrm{GaCl}_{3}$ in ionic liquid EtMeIm- $\mathrm{Tf}_{2} \mathrm{~N}$ at $308 \mathrm{~K}$. Working and reference electrodes were metal tungsten electrodes and scan rate was $0.1 \mathrm{~V} / \mathrm{s}$ [modified from Fig. 1. of ref. 56]. 
spectra of gallium trichloride solution in ion liquid EtMeIm- $\mathrm{Tf}_{2} \mathrm{~N}$ showed the presence of the complex $\mathrm{GaCl}_{4}{ }^{-}$and the heterocomplex $\mathrm{GaOCl}_{3}{ }^{2-}$.

Gasparotto et al. ${ }^{57)}$ investigated the redox behavior of $\mathrm{Ga}$ on $\mathrm{Au}(111)$ from $0.5 \mathrm{M} \mathrm{GaCl}_{3}$ in the air and water-stable ionic liquid 1-butyl-1-methylpyrrolidinium bis(trifluoromethylsulfonyl)amide, $\left[\mathrm{Py}_{1,4}\right] \mathrm{TFSA}$, by cyclic voltammetry. The CV showed two redox processes. The authors explained that the one reduction process at $-0.3 \mathrm{~V}$ (vs. Pt) was attributed to a $\mathrm{Ga}$ deposition on a Ga mono layer formed during an electroless deposition process at OCP and/or to the formation of a Au-Ga alloy and the other one at $-0.9 \mathrm{~V}$ was due to the bulk deposition of Ga. Two anodic peaks in the reverse scan were due to the partial dissolution of gallium from the bulk phase and the alloy. They reported that the gallium electroless deposition did not take place on glassy carbon or platinum but on gold.

\subsection{Anodic oxidation of gallium electrode}

The Ga anodic behaviors in alkaline media were studied by several authors. The results of studies on the anodic behavior of a gallium electrode draw various mechanisms and procedures because the gallium electrode is covered with oxide or hydroxide passive film during anodic oxidation of a gallium electrode. Nikitin et al. ${ }^{58)}$ reported that anodic films formed in a basic solution consisted of the $\mathrm{GaO}(\mathrm{OH})$ (gallium oxohydroxide). Armstrong et al. ${ }^{33)}$ pointed formation of gallium oxide $\left(\mathrm{Ga}_{2} \mathrm{O}_{3}\right)$ or gallium hydroxide $\left(\mathrm{Ga}(\mathrm{OH})_{3}\right)$ on the gallium surface.

Perkins ${ }^{59)}$ studied anodic oxidation of gallium as a working electrode in basic solutions and obtained cyclic voltammograms with a small potential range and a large potential range (Fig. 5).

Perkins presumed that oxide formed at both $\mathrm{A}_{1}$ and $\mathrm{A}_{2}$
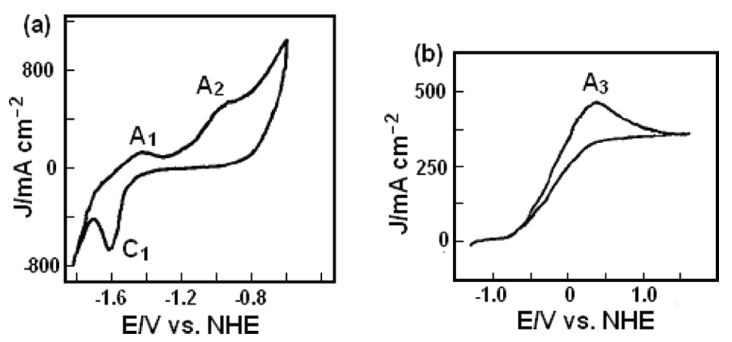

Fig. 5. Current-potential curves for spherical Ga electrode (a) in $3 \mathrm{M} \mathrm{NaOH}$ at a sweep rate of $16.9 \mathrm{~V} / \mathrm{s}$ and (b) in $1 \mathrm{M}$ $\mathrm{NaOH}$ at a sweep rate of $0.60 \mathrm{~V} / \mathrm{s}$ [modified from Figs. 1 and 2 of ref. 59]. was possibly $\mathrm{Ga}_{2} \mathrm{O}_{3}$ or chemisorbed oxygen. At higher potentials $\left(\mathrm{A}_{3}\right)$ the reaction product might be $\mathrm{GaO}_{3}{ }^{3-}$ dissolved in solution. There was not a cathodic peak corresponding to another anodic peak, $\mathrm{A}_{3}$ and it was considered that the absence of a cathodic peak was due to the rapid diffusion of oxidation products. Perkins also observed the hydrogen evolution with oxidation of $\mathrm{Ga}$ in the far anodic region by galvanostatic charging. It was assumed that the hydrogen evolution occurred according to the following mechanism: ${ }^{60}$

$$
\begin{aligned}
& \mathrm{Ga}+\mathrm{OH}^{-} \rightarrow \mathrm{Ga}(\mathrm{OH})_{\mathrm{ads}}+\mathrm{e}^{-} \\
& \mathrm{Ga}(\mathrm{OH})_{\mathrm{ads}}+\mathrm{OH}^{-} \rightarrow \mathrm{Ga}(\mathrm{OH})_{2}^{-} \\
& \mathrm{Ga}(\mathrm{OH})_{2}^{-}+2 \mathrm{H}_{2} \mathrm{O} \rightarrow\left[\mathrm{Ga}(\mathrm{OH})_{4}\right]^{-}+\mathrm{H}_{2}
\end{aligned}
$$

Varadharaj and Prabhakara Rao studied the electrochemical behavior a gallium film electrode in $\mathrm{NaOH}$ solutions. ${ }^{61-63)}$ First, the authors ${ }^{61)}$ obtained reproducible and characteristic cyclic voltammograms of gallium films formed on copper electrodes and the features of the CVs consisting of three anodic peaks and one cathodic peak were in good agreement with Perkin's data. ${ }^{59,64)}$ Varadharaj and Prabhakara Rao ${ }^{62)}$ could observe the one anodic current peak $\left(\mathrm{A}^{*}\right)$ during cathodic sweep from cyclic voltammetric studies (Fig. 6) measured on a gallium film electrode in 0.1-6 M $\mathrm{NaOH}$ solutions. The authors performed cyclic volta-
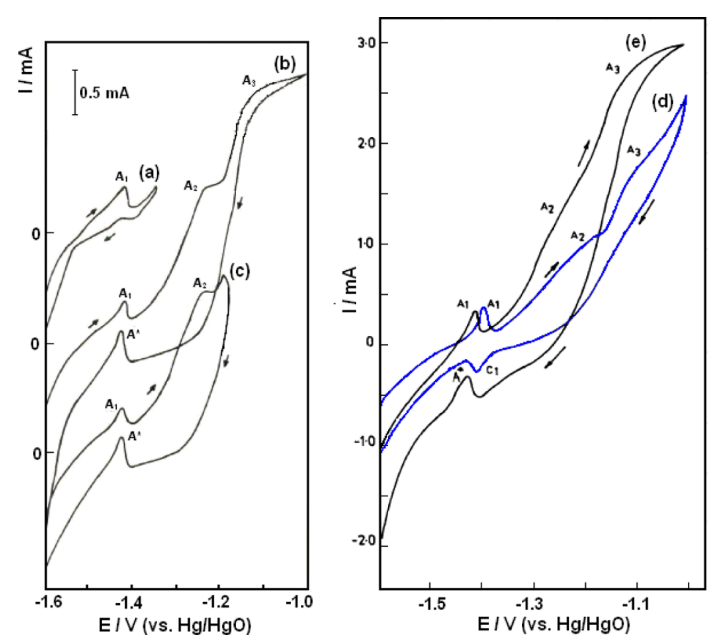

Fig. 6. Cyclic voltammograms of gallium film electrode in $6 \mathrm{M} \mathrm{NaOH}$ at sweep rates of $40 \mathrm{mV} / \mathrm{s}$. with scan reversals at (a) -1.35 , (b) -1.00 , and (c) $-1.20 \mathrm{~V}$ [modified from Fig. 1 of ref. 62], in (d) $0.5 \mathrm{M} \mathrm{NaOH}$, at a sweep rate of $100 \mathrm{mV} / \mathrm{s}$ and (e) $3.0 \mathrm{M} \mathrm{NaOH}$, at a sweep rate of $40 \mathrm{mV} / \mathrm{s}$ [modified from Fig. 1 of ref. 63]. 
mmetric experiments in which potential reversals had been performed at various stages of oxidation (after $A_{1}$, after $A_{2}$, or after $\left.A_{3}\right)$. Cyclic voltammograms revealed that the second anodic peak $\left(\mathrm{A}^{*}\right)$ was enhanced when $\mathrm{A}_{2}$ was included. The authors indicated that the formation of a lower valent intermediate such as monovalent gallium species might yield the unusual second anodic peak ( $\left.\mathrm{A}^{*}\right)$.

In the authors' further study, ${ }^{63)}$ they suggested the mechanism of different stages of the anodic oxidation of gallium from the analysis of three anodic peaks and one cathodic peak observed in cyclic voltammograms. From Pourbaix diagram it was assumed that the anodic oxidation of a gallium film in alkaline media proceeded through reactions as following:

$$
\begin{aligned}
& \mathrm{Ga}+3 \mathrm{H}_{2} \mathrm{O} \rightleftharpoons \mathrm{Ga}(\mathrm{OH})_{3}+3 \mathrm{H}^{+}+3 \mathrm{e}^{-} \\
& 2 \mathrm{Ga}+3 \mathrm{H}_{2} \mathrm{O} \rightleftharpoons \mathrm{Ga}_{2} \mathrm{O}_{3}+6 \mathrm{H}^{+}+6 \mathrm{e}^{-}
\end{aligned}
$$

First, the authors suggested the possibility of the oxidation of gallium through reaction (10) with the alkali concentration less than $1.0 \mathrm{M} \mathrm{NaOH}$. In the alkali concentration higher than $1.0 \mathrm{M} \mathrm{NaOH}$, the oxidation of gallium seemed to involve reaction (11). From the analysis of two anodic peaks observed at more positive potentials, the oxidation mechanism including a one-electron transfer oxidation (12) and a two-electron transfer oxidation (13) was suggested:

$$
\begin{aligned}
& 2 \mathrm{Ga}+\mathrm{H}_{2} \mathrm{O} \rightleftharpoons \mathrm{Ga}_{2} \mathrm{O}+2 \mathrm{H}^{+}+2 \mathrm{e}^{-} \\
& \mathrm{Ga}_{2} \mathrm{O}+2 \mathrm{H}_{2} \mathrm{O} \rightarrow \mathrm{Ga}_{2} \mathrm{O}_{3}+4 \mathrm{H}^{+}+4 \mathrm{e}^{-}
\end{aligned}
$$

$\mathrm{Ga}_{2} \mathrm{O}$, being an unstable product, could be expected to disproportionate giving $\mathrm{Ga}$ metal and $\mathrm{Ga}_{2} \mathrm{O}_{3}$ as a step (14):

$$
3 \mathrm{Ga}_{2} \mathrm{O} \stackrel{\text { disproportionate }}{\longrightarrow} 4 \mathrm{Ga}+\mathrm{Ga}_{2} \mathrm{O}_{3}
$$

They reported that one can observe pronounced accumulation of $\mathrm{Ga}_{2} \mathrm{O}$ and its disproportionation (Eq.14) under the condition of low alkali and slow sweep rates. Korshunov ${ }^{65)}$ approached the anodic behavior of the rotating disk Ga electrode in alkaline media with the structure of anodic films. The author assumed that the anodic film is $\mathrm{Ga}(\mathrm{OH})_{3}, \mathrm{Me}\left[\mathrm{Ga}(\mathrm{OH})_{4}\right]_{\mathrm{z}}$ or $\mathrm{GaO}(\mathrm{OH})$. He considered which of the following pathways most convincingly agreed with the experimental data.

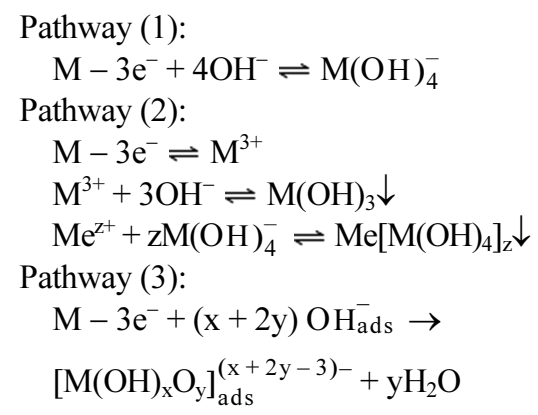

Pathway (1) yields very stable metallate ions under the condition of interest and does not form films on the electrode surface. For pathway (2), $\mathrm{M}(\mathrm{OH})_{3}$ is produced at low concentration of alkali (16a) whereas at high concentration, hydroxides give way to metallate ions and passivating layer is formed with background cation $\left(\mathrm{Me}^{\mathrm{z}+}\right)$ (16b). Pathway (3) describes ionization under the conditions of direct electrosynthesis of the passivating film on the electrode surface. The author concluded that ionization of solid gallium in a $\mathrm{NaOH}$ solution led to the direct formation of thin barrier layers of $\mathrm{GaO}(\mathrm{OH})$ on $\mathrm{Ga}$ electrode surface through reaction (17) $(\mathrm{x} \approx \mathrm{y} \approx 1)$ from the analysis of experiment data. Korshunov also suggested the multistage process to describe the ionization of gallium and the breakdown of anodic films on the gallium metal by aggressive anions in a solution of high $\mathrm{pH}$ through further study. ${ }^{66)}$ The author showed that chloride-containing complex ions or coordinate compounds might be formed as a result of adding aggressive anions, $\mathrm{Cl}^{-}$. Adding anions $\left(\mathrm{An}^{-}\right.$, for example, $\left.\mathrm{Cl}^{-}\right)$into electrolyte gave rise to mixed ligand compounds (soluble among them) through reaction (18) or (19):

$$
\begin{aligned}
& \mathrm{M}+(\mathrm{x}+2 \mathrm{y}) \mathrm{OH}_{\mathrm{ads}}^{-}+\mathrm{pAn}-\mathrm{n}_{\mathrm{ads}}^{-}-3 \mathrm{e}^{-} \\
& \rightarrow\left[\mathrm{M}(\mathrm{OH})_{\mathrm{x}} \mathrm{O}_{\mathrm{y}} \mathrm{An}_{\mathrm{p}}\right]_{\mathrm{ads}}^{(\mathrm{x}+2 \mathrm{y}+\mathrm{p}-3)-}+\mathrm{yH}_{2} \mathrm{O} \\
& {\left[\mathrm{M}(\mathrm{OH})_{\mathrm{x}} \mathrm{O}_{\mathrm{y}}\right]_{\mathrm{ads}}^{(\mathrm{x}+2 \mathrm{y}-3)^{-}}+\mathrm{pAn}_{\mathrm{ads}}^{-}+\mathrm{yH}_{2} \mathrm{O}_{\mathrm{ads}}} \\
& \rightarrow\left[\mathrm{M}(\mathrm{OH})_{\mathrm{x}+2 \mathrm{y}-\mathrm{p}} \mathrm{An}_{\mathrm{p}}\right]_{\mathrm{ads}}^{(\mathrm{x}+2 \mathrm{y}-3)-}+\mathrm{pOH}^{-}
\end{aligned}
$$

Poorly soluble polymeric films of the composition $\mathrm{M}(\mathrm{OH})_{\mathrm{x}} \mathrm{Cl}_{3-\mathrm{x}}$ might result from the process of the generation of an unstable dimmer (20) and its decomposition (21):

$$
\begin{aligned}
& 2 \mathrm{Ga}+4 \mathrm{Cl}_{\text {ads }}^{-}-4 \mathrm{e}^{-} \rightarrow \mathrm{Cl}_{2} \mathrm{Ga}-\mathrm{GaCl}_{2}(\mathrm{aq}) \\
& \mathrm{Cl}_{2} \mathrm{Ga}-\mathrm{GaCl}_{2}(\mathrm{aq})+2 \mathrm{H}_{2} \mathrm{O} \rightarrow 2 \mathrm{Ga}(\mathrm{OH}) \mathrm{Cl}_{2}+\mathrm{H}_{2}
\end{aligned}
$$


Concurrently with the synthesis, the $\mathrm{Ga}(\mathrm{OH})_{\mathrm{x}} \mathrm{Cl}_{3-\mathrm{x}}$ compound disappears according to the scheme (22):

$$
\begin{aligned}
& {\left[\mathrm{M}(\mathrm{OH})_{\mathrm{x}} \mathrm{Cl}_{3-\mathrm{x}}\right]_{\mathrm{ads}}+(4-\mathrm{x}) \mathrm{OH}^{-}(\mathrm{aq})} \\
& \rightarrow \mathrm{M}(\mathrm{OH})_{4}^{-}(\mathrm{aq})+(3-\mathrm{x}) \mathrm{Cl}^{-}(\mathrm{aq})
\end{aligned}
$$

Tsvetanova et al. ${ }^{67)}$ investigated the processes with respect to the oxidation of gallium in acidic solution. A series of I-E curves for a gallium electrode including Fig. 7 showed several anodic maxima in the three potential regions. In the first region the processes might be related to the oxidation of gallium to the monovalent state (Eq. 23) and to the ionization of $\mathrm{H}_{2}{ }^{+}$ adsorbed on the gallium electrode (Eq. 24).

$$
\begin{aligned}
& \mathrm{Ga}+\mathrm{H}_{2} \mathrm{O} \rightarrow \mathrm{GaOH}_{\mathrm{ads}}+\mathrm{H}^{+}+\mathrm{e}^{-} \\
& \mathrm{H}_{2 \text { ads }}^{+} \rightarrow 2 \mathrm{H}^{+}+\mathrm{e}^{-}
\end{aligned}
$$

In the second region, the processes included the electrochemical oxidation (Eq. 25) or chemical oxidation (Eq. 27) of the adsorbed product of reaction (23) and further oxidation of the gallium surface not covered with the adsorbed product:

$$
\begin{aligned}
& \mathrm{GaOH}_{\mathrm{ads}}+\mathrm{H}_{2} \mathrm{O} \rightarrow \mathrm{Ga}(\mathrm{OH})_{2}^{+}+\mathrm{H}^{+}+2 \mathrm{e}^{-} \\
& \mathrm{Ga}(\mathrm{OH})_{2}^{+}+2 \mathrm{H}^{+} \rightarrow \mathrm{Ga}^{3+}+2 \mathrm{H}_{2} \mathrm{O} \\
& \mathrm{GaOH}_{\mathrm{ads}}+\mathrm{H}_{2} \mathrm{O}+\mathrm{H}^{+} \rightarrow \mathrm{Ga}(\mathrm{OH})_{2}^{+}+\mathrm{H}_{2}
\end{aligned}
$$

It was considered that in the most positive potential region (more positive region than $-0.3 \mathrm{~V}$ ) a coating

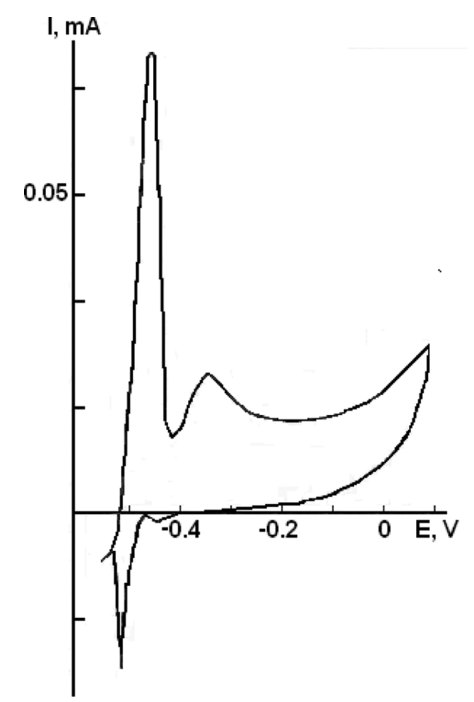

Fig. 7. I-E curve for a gallium electrode in $0.5 \mathrm{M} \mathrm{Na}_{2} \mathrm{SO}_{4}$ at $\mathrm{pH} 2$ and $40^{\circ} \mathrm{C}$ [modified from Fig. 2 of ref. 67]. grew on the electrode.

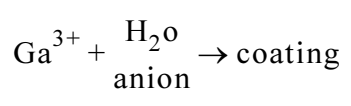

Gasanly and Guseinzaden ${ }^{68)}$ studied kinetics and mechanism of the anodic dissolution of gallium in an anhydrous acetic acid medium. Results showed the further reactions of stable $\mathrm{Ga}^{+}$ions formed via anodic dissolution of gallium metal in a $0.5 \mathrm{M} \mathrm{LiCl}$ solution in $100 \% \mathrm{CH}_{3} \mathrm{COOH}$. In the course of anodic polarization of a gallium, $\mathrm{Ga}^{+}$ions formed through the reaction (29) were oxidized to $\mathrm{Ga}^{3+}$ (Eq. 30) or were spent by the DPP (Eq. 2):

$$
\begin{aligned}
& \mathrm{Ga}^{0} \rightarrow \mathrm{Ga}^{+}+\mathrm{e}^{-} \\
& \mathrm{Ga}^{+} \rightarrow \mathrm{Ga}^{3+}+2 \mathrm{e}^{-} \\
& 3 \mathrm{Ga}^{+} \rightarrow 2 \mathrm{Ga}^{0}+\mathrm{Ga}^{3+}
\end{aligned}
$$

The limiting current ( $i_{\mathrm{r}}$ )of the oxidation of $\mathrm{Ga}^{+}$ions and the stability coefficient of $\mathrm{Ga}^{+}, \mathrm{k}_{\mathrm{s}}\left(\mathrm{i}_{1} / \mathrm{i}_{\mathrm{d}}\right)$ increased with the increase of temperature ranged from 20 to $35^{\circ} \mathrm{C}$ and were reached a maximum at $35^{\circ} \mathrm{C}$. They suggested that decreases in the $\mathrm{i}_{\mathrm{r}}$ and $\mathrm{k}_{\mathrm{s}}$ at higher temperature than $35^{\circ} \mathrm{C}\left(40,45\right.$, and $\left.50^{\circ} \mathrm{C}\right)$ were due to the increase in the oxidation rate of $\mathrm{Ga}^{+}$with hydrogen ions:

$$
\mathrm{Ga}^{+}+2 \mathrm{H}^{+} \rightarrow \mathrm{Ga}^{3+}+\mathrm{H}_{2}
$$

The anodic oxidation of gallium electrodes gave rise to passivating layers in both alkaline and acidic solutions. Passivating layers consisting of $\mathrm{Ga}(\mathrm{OH})_{3}$ were formed in a low concentration alkaline solution and $\mathrm{GaO}(\mathrm{OH})$ barrier layers are formed in an alkali solution of high concentration. In an acidic solution, coatings, as salts of $\mathrm{Ga}^{3+}$ with anions or $\mathrm{H}_{2} \mathrm{O}$ grew on a gallium surface via an adsorbed oxidation product, $\mathrm{GaOH}_{\mathrm{ads}}$, and soluble $\mathrm{Ga}^{3+}$ species, $\mathrm{Ga}(\mathrm{OH})_{2}{ }^{+}$.

\section{Electrodeposition of Gallium}

\subsection{Electrodeposition of gallium}

Flamini et al. ${ }^{69)}$ investigated gallium electrodeposition onto vitreous carbon in $0.5 \mathrm{M} \mathrm{Cl}^{-}$at the $\mathrm{pH}$ of 2.5 . The authors compared electrodepositions under stagnant condition and non-stagnant condition. The electrodeposition of gallium onto vitreous carbon required high overvoltages. It was considered that under stagnant condition at more positive potentials than $-1.58 \mathrm{~V}$ (vs. SCE), the reduction to $\mathrm{Ga}^{+}$species took place and 


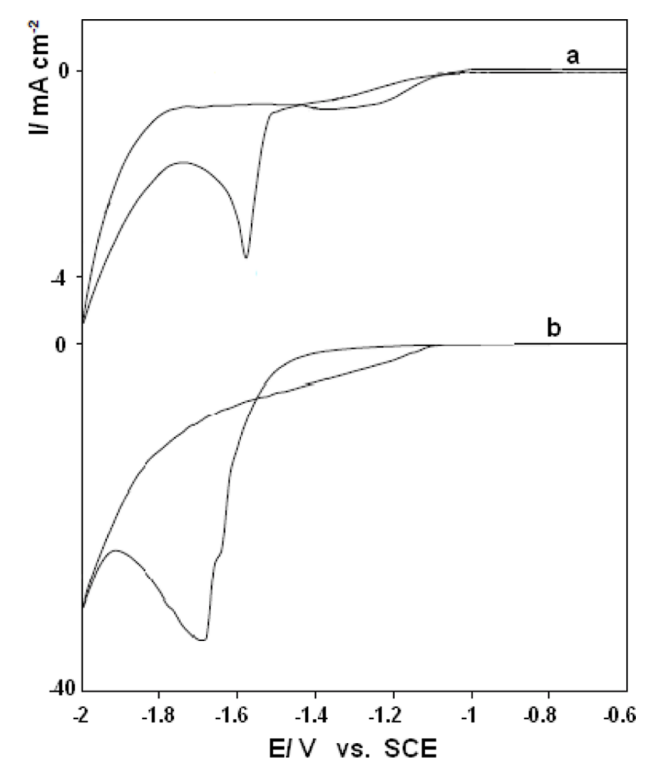

Fig. 8. Voltammetric responses of vitreous carbon in $0.5 \mathrm{M}$ $\mathrm{Cl}^{-}, \mathrm{pH} 2.5$ solution containing $0.01 \mathrm{M} \mathrm{Ga}^{3+}$ (a) without electrode rotation and (b) with electrode rotation of 800 rpm. Sweeprate: $0.02 \mathrm{~V} / \mathrm{s}$ [modified from Figs. 1 and 7 of ref. 69].

at more negative potentials than $-1.58 \mathrm{~V}$, the nucleation of $\mathrm{Ga}$ initiated. The nucleation was progressive controlled by diffusion. The absence of oxidation peaks in the positive scan of potentiodynamic measurements indicated that deposited Ga was already oxidized by local alkalinisation from hydrogen evolution. Under the electrode rotation of $800 \mathrm{rpm}$, the nucleation of electrodeposited Ga initiated at $-1.64 \mathrm{~V}$ and no oxidation of deposited $\mathrm{Ga}$ was detected.

Al Zoubi et al. ${ }^{70)}$ reported the electrochemical synthesis of gallium nanostructures in an ionic liquid. Gallium nanowires and macroporous structures were synthesized by the template-assisted electrodeposition in the ionic liquid 1-butyl-1-methylpyrrolidinium bis(trifluoromethylsulfonyl)amide ([Py $\left.\left.\mathrm{P}_{1,4}\right] \mathrm{TFSA}\right)$ containing $\mathrm{GaCl}_{3}$ as the precursor. The electrochemical behaviors of $\mathrm{GaCl}_{3}$ in $\left[\mathrm{Py}_{1,4}\right]$ TFSA inside templates were investigated by CVs as shown in Fig. 9. The authors assumed that at a potential of $-1.5 \mathrm{~V}$ (vs. Pt) the electrodeposition of Ga occurred on Pt inside the polycarbonate membrane followed by the electrodeposition on deposited Ga at $-2.7 \mathrm{~V}$. Gallium nanowires were obtained by applying a potential of $-2.4 \mathrm{~V}$ for $30 \mathrm{~min}$. The electrodeposition of $\mathrm{Ga}$ on ITO-glass inside the polystyrene colloidal crystal tem-

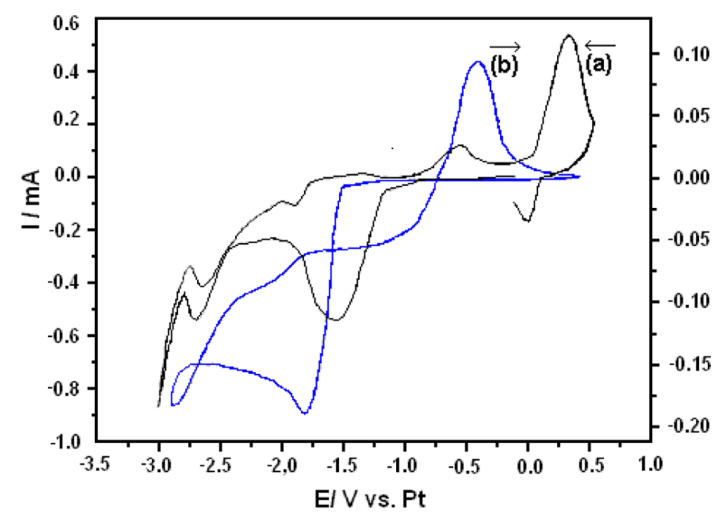

Fig. 9. Cyclic voltammograms of $0.5 \mathrm{M} \mathrm{GaCl}_{3}$ in [Py1,4] TFSA at a scan rate of $10 \mathrm{mV} / \mathrm{s}$ and at $25^{\circ} \mathrm{C}$ (a) on a $\mathrm{Pt}$ electrode inside the polycarbonate membranes and (b) on an ITO electrode inside the polystyrene colloidal crystal templates [modified from Figs. 1 and 5 of ref. 70].

plate (600 nm average sphere size) from $0.5 \mathrm{M} \mathrm{GaCl}_{3}$ in $\left[\mathrm{Py}_{1,4}\right] \mathrm{TFSA}$ solution took plate at a applied potential of $-1.75 \mathrm{~V}$.

\subsection{Electrochemistry associated with the recovery of gallium via electrodeposition}

The interest in the recovery of gallium metal arises from its unique properties and its expanding uses in solid-state electronic devices, the nuclear industry and optics. Gallium invariably associated with bauxite, is dissolved into sodium aluminate solution as sodium gallate during the digestion of bauxite in alkaline media. The concentration of gallium in the liquor is very low and so the extraction of gallium is mainly carried out by an amalgam metallurgical process using a mercury or sodium amalgam cathode and a steel anode in an electrolytic cell.

Kozin et al ${ }^{71)}$ studied the electrochemical behavior of gallium at mercury electrodes in alkaline gallate solutions. In the electrolysis of the sodium aluminate solution on a mercury cathode, first, sodium ions were discharged at the mercury cathode yielding sodium amalgam and later the gallium present in solution passed into the mercury phase through an exchange reaction:

$$
\begin{aligned}
& \mathrm{Na}_{3}(\mathrm{Hg})_{\mathrm{x}}+\mathrm{GaO}_{2}^{-}+2 \mathrm{H}_{2} \mathrm{O} \\
& \rightleftharpoons \mathrm{Ga}(\mathrm{Hg})_{\mathrm{x}}+3 \mathrm{NaOH}+\mathrm{OH}^{-}
\end{aligned}
$$

The gallate ion discharge at the mercury cathode occured with significant overpotential. It could be con- 
sidered that the highly negative charge of the mercury cathode surface in alkaline gallate solution hindered the approach of the negatively charged gallate ions to the electrode surface. The sodium ions are discharged at mercury cathodes at more positive potential due to the high affinity between the sodium and mercury that lead to the formation of intermetallic compounds, $\mathrm{NaHg}_{2}, \mathrm{NaHg}_{4}$, etc. The surface of the sodium amalgam electrode was charged positively, so that phaseexchange of the negatively charged gallate ions with the surface of positively charged sodium amalgam could occur without hindrance. Varadharaj et al. ${ }^{72)}$ studied cyclic voltammograms on hanging mercury drop electrodes for alkaline gallate solutions in order to obtain the basic information of the exchange reaction between sodium amalgam and Ga(III). If the exchange reaction took place according to the Eq. (32) suggested by Kozin et al. ${ }^{71)}$ one might expect that the amount of gallium accumulated in the mercury phase should depend on the gallate concentration, the amount of sodium in the amalgam, and the time of contact of the sodium amalgam with the gallate in the solution. In their measured CVs increases in the gallate concentration and the $\mathrm{NaOH}$ concentration in solution had brought an increase in the anodic peak height for gallium dissolution. And the slower the scan rate, the anodic peak height increased. These results pointed to the involvement of the exchange reaction between the sodium deposited and the gallate in solution.

The electrodeposition of gallium from sodium aluminate solutions occurs in parallel with the hydrogen evolution reaction. Dorin and Frazer ${ }^{73)}$ found that copper as a working electrode was the most suitable material as it was readily 'wetted' by the depositing gallium with which it formed alloys and the resulting gallium film on a copper electrode showed an enhanced hydrogen overpotential.

The aluminate liquor from alkaline digestion of bauxite normally includes metallic and organic impurities. It is noted that these impurities inhibit the reduction of gallium in the process of recovery of gallium from the alkaline aluminate liquor. The effects of metals ${ }^{73,74)}$ and organic compounds ${ }^{72,75)}$ involved in the aluminate liquor as impurities on gallate reduction were investigated. Varadharaj et al. ${ }^{72,74,75)}$ observed that the anodic peak height in the stripping curve of the gallium decreased as the concentration of metallic ( $\mathrm{V}, \mathrm{Fe}, \mathrm{Cu}, \mathrm{Zn}, \mathrm{Pb}$ etc.) and organic impurities (oxalic acid, ascorbic acid, p-amino toluene, and metanilic acid) increased. In the case of nitrobenzoic acid as an organic impurity, the pronounced effect on the hydrogen evolution reaction was shown. Dorin and Frazer ${ }^{73)}$ confirmed that heavy metal impurities, such as iron and vanadium, promoted the hydrogen evolution reaction and inhibited gallium production when present above certain critical concentrations. They also determined the limiting levels of iron and vanadium for successful gallium electrodeposition.

Paciej et al. ${ }^{76)}$ employed microelectrodes to enhance the rate of mass transport and thus to increase the rate of gallium recovery. Potentiostatic plating and stripping experiments were performed using copper electrodes ranging in diameter from $1 \mathrm{~cm}$ down to $45 \mu \mathrm{m}$. In this work they demonstrated that the rate of recovery was found to be higher on microelectrodes than on a large plate electrode. They suggested that the use of ensembles of microelectrodes for the electrolytic recovery of gallium would become very effective, compared to a large electrode.

\subsection{Electrodeposition of gallium alloys}

Paolucci et al ${ }^{77)}$ prepared GaSb polycrystalline thin films by two-step electrodeposition of $\mathrm{Sb}$ and Ga films and a mild thermal annealing (at $100^{\circ} \mathrm{C}$ for $4 \mathrm{~h}$ ). Nickel-plated $\mathrm{Cu}$ sheets were chosen as substrates for the preparation of GaSb films. Antimony was deposited potentiostatically at $-0.25 \mathrm{~V}$ vs. SCE in acidic bath solutions and a periodic $(5 \mathrm{~s})$ switching of the working potential from $-0.25 \mathrm{~V}$ to the rest potential of $-0.15 \mathrm{~V}$ was needed. Gallium was potentiostatically deposited from $5 \mathrm{M} \mathrm{KOH}$ solutions containing $0.3 \mathrm{M}$ $\mathrm{GaCl}_{3}$ at $-1.85 \mathrm{~V}$. An alternative approach based on the one-step deposition of $\mathrm{Sb}$ and $\mathrm{Ga}$ was unsuccessful.

Kois et al. ${ }^{78)}$ prepared Cu-In-Ga (CIG) layers on Mo-coated soda lime glass electrodes by one-step electrodeposition from thiocyanate complex electrolytes. As the electrolyte was agitated, the deposition rate of both copper and indium increased, while gallium deposited at a constant rate. Therefore it was known that the gallium concentration in the CIG film depended on the stirring rate.

Lai et $a l .{ }^{79)}$ investigated cyclic voltammetries of $\mathrm{Cu}$, $\mathrm{Se}, \mathrm{In}$, and $\mathrm{Ga}$ on $\mathrm{SnO}_{2}$-coated glass electrodes in a DMF-aqueous solution that contained citrate as a complexing agent. They proposed that the insertion of In and $\mathrm{Ga}$ into the solid phase might proceed by an underpotential deposition mechanism which involved 
two different routes: $\mathrm{In}^{3+}$ and $\mathrm{Ga}^{3+}$ reduction by a surface-induced effect from $\mathrm{Cu}_{3} \mathrm{Se}_{2}$ and/or a reaction with $\mathrm{H}_{2} \mathrm{Se}$. The same research group also reported ${ }^{80)}$ the incorporation mechanism of gallium during electrodeposition of $\mathrm{Cu}(\mathrm{In}, \mathrm{Ga}) \mathrm{Se}_{2}$ thin film from chloride electrolytes using sodium sulfamate as a complexing agent. The insertion of gallium involved two different routes: firstly, $\mathrm{Ga}^{3+}$ reacted with $\mathrm{H}_{2} \mathrm{Se}$ to form gallium selenide $\left(\mathrm{Ga}_{2} \mathrm{Se}_{3}\right)$; secondly $\mathrm{Ga}_{2} \mathrm{O}_{3}$ was formed via hydrolysis of $\mathrm{Ga}^{3+}$ due to the increase of local $\mathrm{pH}$. It was seemed that $\mathrm{Ga}_{2} \mathrm{Se}_{3}$ phase dispersed in the $\mathrm{Cu}(\mathrm{In}, \mathrm{Ga}) \mathrm{Se}_{2}$ thin films in the form of nanocrystalline. They observed that the $\mathrm{Ga}_{2} \mathrm{O}_{3}$ peak appeared in the CIGS thin films deposited at -0.2 and $-0.3 \mathrm{~V}$ from the Raman spectra.

Iselt et al. ${ }^{81)}$ deposited $\mathrm{Fe}-\mathrm{Ga}$ films onto $\mathrm{Au}$ or $\mathrm{Pt}$ coated Si substrates by potentiostatic deposition and pulse potential deposition. The electrolyte used in this study consisted of an aqueous solution of $0.3 \mathrm{M}$ $\mathrm{FeSO}_{4}, 0.06 \mathrm{M} \mathrm{Ga}_{2}\left(\mathrm{SO}_{4}\right)_{3}, 0.5 \mathrm{M} \mathrm{H}_{3} \mathrm{BO}_{3}$ as a buffer and $0.04 \mathrm{M}$ ascorbic acid as an antioxidant agent, where the $\mathrm{pH}$ was adjusted to 1.5 . The desired composition of $\mathrm{Fe}-\mathrm{Ga}$ films, $\mathrm{Fe}_{80} \mathrm{Ga}_{20}$ was obtained on $\mathrm{Pt}$ coated Si substrates. Pulse deposition was performed at $\mathrm{E}_{1}=-1.5 \mathrm{~V}$ and $\mathrm{E}_{2}=-0.9 \mathrm{~V}$. Both potentials were applied 60 times for $t_{1}=t_{2}=10 \mathrm{~s}$. Using optimized pre-treatment (immersing the working electrode into the electrolyte under applied deposition potential) and pulsed potential conditions the films were dense and homogeneous and the oxygen content was reduced to less than 1 at.\%. Reddy et al. ${ }^{82)}$ fabricated arrays of magnetostrictive $\mathrm{Fe}-\mathrm{Ga} / \mathrm{Cu}$ multilayered nanowires using pulsed electrodeposition in nanoporous anodic aluminium oxide templates that had been coated with $\mathrm{Ti}$ and Au sequentially. Electrodepositions were carried out in a citrate-based electrolytic bath containing $\mathrm{FeSO}_{4}(15 \mathrm{mM}), \mathrm{Ga}_{2}\left(\mathrm{SO}_{4}\right)_{3}(17 \mathrm{mM})$, and $\mathrm{CuSO}_{4}(1.5$ $\mathrm{mM}$ ) at potentials of $-1.12 \mathrm{~V}$ and $-0.8 \mathrm{~V}$ vs. $\mathrm{Ag} / \mathrm{AgCl}$ for $\mathrm{Fe}-\mathrm{Ga}$ and $\mathrm{Cu}$ depositions, respectively.

Carpenter and Verbrugge ${ }^{83)}$ studied the electrochemical codeposition of gallium and arsenic from a room temperature melt comprised of $\mathrm{GaCl}_{3}, \mathrm{ImCl}$ (1methyl-3-ethylimidazolium chloride) and $\mathrm{AsCl}_{3}$. Ga and As could be codeposited between -0.4 and $-1 \mathrm{~V}$ (vs. Al reference electrode) in a $40: 60 \mathrm{GaCl}_{3}-\mathrm{ImCl}$ melt. The deposition of gallium metal from $\mathrm{GaCl}_{3}$ $\mathrm{ImCl}$ melt was presumed to proceed according to Eqs. (33) and (34):

$$
\begin{aligned}
& \mathrm{GaCl}_{3}+\mathrm{ImCl} \rightleftharpoons \mathrm{Im}^{+}+\mathrm{GaCl}_{4}^{-} \\
& \mathrm{GaCl}_{4}^{-}+3 \mathrm{e}^{-} \rightleftharpoons \mathrm{Ga}+4 \mathrm{Cl}_{4}^{-}
\end{aligned}
$$

\section{Kinetic Parameters}

\subsection{Heterogeneous rate constants and charge transfer coefficients}

Heterogeneous rate constant is a measure of the kinetic facility of a redox couple on an electrode. Moorhead and Frame ${ }^{84)}$ measured the apparent heterogeneous rate constant, $\mathrm{k}_{\mathrm{s}}$, for the polarographic gallium electrode reaction in the presence of $\mathrm{SCN}^{-}$. The heterogeneous rate constant of $\mathrm{Ga}(\mathrm{III})$ in an acidic solution of $\mathrm{pH} 1$ containing $1 \mathrm{mM} \mathrm{Ga}(\mathrm{III}), 0.05 \mathrm{M}$ $\mathrm{NaSCN}$, and $6.0 \mathrm{M} \mathrm{NaClO}_{4}$ was $0.016 \mathrm{~cm} / \mathrm{sec}$. Sharma and Gupta obtained the kinetic parameters of the electrode reactions of gallium-amino acid complexes using DL $\alpha$-alanine ${ }^{85)}$ and L-glutamine ${ }^{52)}$ as ligands. The formal rate constant $\left(\mathrm{k}_{\mathrm{f}, \mathrm{h}}^{0}\right)$ of the reduction of the $\mathrm{Ga}$ (III)-complex was calculated by Koutecky's treatment extended by Meites and Israel ${ }^{86)}$ as Eqs. (35) and (36) (at 298K):

$$
\begin{aligned}
& E_{d, e}=E_{1 / 2}-\frac{0.0542}{\alpha n_{a}} \log \frac{i}{i_{d}-i} \\
& E_{1 / 2}=\frac{0.05915}{\alpha n_{a}} \log \frac{1.349 \mathrm{k}_{\mathrm{f}, \mathrm{h}^{1 / 2}}^{0}}{\mathrm{D}^{1 / 2}}
\end{aligned}
$$

Table 1. Rate constants and associated parameters for $\mathrm{Ga}(\mathrm{III})-\mathrm{DL} \alpha$-alanine in $0.001 \mathrm{M} \mathrm{Ga}(\mathrm{III}), 0.1 \mathrm{M} \mathrm{KCl}$, at $\mathrm{pH} 3.5$, and at $30^{\circ} \mathrm{C}$ (data* were obtained at $40^{\circ} \mathrm{C}$ ). ${ }^{85}$ )

\begin{tabular}{cccccc}
\hline Conc. of ligand(M) & $-\mathrm{E}_{1 / 2}(\mathrm{~V}$ vs. SCE $)$ & $\mathrm{i}_{\mathrm{d}}(\mu \mathrm{A})$ & $\mathrm{a}$ & $\mathrm{k}_{\mathrm{f}, \mathrm{h}}(\mathrm{cm} / \mathrm{s})$ & $\mathrm{D}^{1 / 2}\left[\left(\mathrm{~cm}^{2} / \mathrm{s}\right)^{1 / 2}\right]$ \\
\hline 0.0010 & 1.135 & 7.35 & 0.497 & $1.58 \times 10^{-8}$ & 1.200 \\
0.0015 & 1.138 & 7.15 & 0.488 & $1.33 \times 10^{-8}$ & 0.781 \\
0.0020 & 1.142 & 6.45 & 0.483 & $1.07 \times 10^{-8}$ & 0.528 \\
0.0025 & 1.146 & 6.35 & 0.471 & $8.29 \times 10^{-8}$ & 0.416 \\
0.0030 & 1.155 & 5.10 & 0.473 & $5.83 \times 10^{-9}$ & 0.278 \\
$0.0030^{*}$ & 1.140 & 5.30 & 0.479 & $6.43 \times 10^{-9}$ & 0.289 \\
0.0040 & 1.160 & 4.35 & 0.463 & $4.87 \times 10^{-9}$ & 0.178 \\
\hline
\end{tabular}


As seen in Table $1, \alpha$ and $\mathrm{k}_{\mathrm{f}, \mathrm{h}}^{0}$ decreased with increase of DL $\alpha$-alanine concentration, which implied that the transfer of electrons was more difficult. In other words, the electrode reaction of Ga(III)complexes was rendered increasingly irreversible with an increase in $\mathrm{DL} \alpha$-alanine concentration. The values of $\alpha$ and $\mathrm{k}_{\mathrm{f}, \mathrm{h}}^{0}$ showed an increase with the temperature, the tendency meant that electrode reaction of $\mathrm{Ga}$ (III)complexes became less irreversible as temperature increased.

Kozin and Gaidin ${ }^{53)}$ calculated the kinetic parameters of the electrode processes on liquid gallium electrode in a fluoride-alkaline electrolyte. Their experimental results indicated that cathodic and anodic electrode reactions on gallium proceeded through the formation of mixed complexes. The authors calculate the values of charge transfer coefficients $(\alpha, \beta)$ for the anodic and cathodic processes. It was known that as temperature was elevated from 303 $\mathrm{K}$ to $333 \mathrm{~K}$, the transfer coefficient $(\alpha)$ of the cathodic process increased.

Chen et al. ${ }^{55)}$ obtained the standard heterogeneous rate constant and the charge transfer coefficient of the $\mathrm{Ga}(\mathrm{III}) / \mathrm{Ga}(\mathrm{I})$ couples in the $\mathrm{AlCl}_{3}$-MEIC molten salt $(40: 60 \mathrm{~mol} \%)$ at $30^{\circ} \mathrm{C}$. The authors investigated the charge-transfer kinetics of $\mathrm{Ga}(\mathrm{I})$ oxidation with rotating disk electrode (RDE) voltammetry. They obtained the plots of the current for the oxidation of $\mathrm{Ga}(\mathrm{I})$ at a $\mathrm{RDE}$ as a function of the square root of the angular velocity, $\omega^{1 / 2}$. The standard heterogeneous rate constant was calculated by the relations as shown in Eqs. (37)-(39): $:^{\text {(6) }}$

$$
\begin{aligned}
& \frac{1}{\mathrm{i}}=\frac{1}{\mathrm{i}_{\mathrm{k}}}+\frac{1}{\mathrm{i}_{1, \mathrm{a}}}=\frac{1}{\mathrm{i}_{\mathrm{k}}}+\frac{1}{0.620 \mathrm{nFACDv} v^{-1 / 6} \omega^{1 / 2}} \\
& \mathrm{i}_{\mathrm{k}}=\mathrm{nFAk}_{\mathrm{f}}(\mathrm{E}) \mathrm{C} \\
& \ln _{\mathrm{f}}(\mathrm{E})=\ln \mathrm{k}^{\mathrm{o}}-\frac{\alpha \mathrm{nFE}}{\mathrm{RT}}
\end{aligned}
$$

The $\mathrm{Ga}(\mathrm{III}) / \mathrm{Ga}(\mathrm{I})$ redox reaction at both tungsten and glassy carbon involved slow charge-transfer kinetics. The $\mathrm{Ga}(\mathrm{I}) / \mathrm{Ga}$ (III) electrode reaction exhibited standard heterogeneous rate constants of $3.16 \times 10^{-4}$ and $1.82 \times 10^{-9} \mathrm{~cm} / \mathrm{s}$, at tungsten and glassy carbon, respectively. As seen in Fig. 3, it was known that the $\mathrm{Ga}(\mathrm{I}) / \mathrm{Ga}(\mathrm{III})$ electrode reaction at glassy carbon was more irreversible than the electrode reaction at tungsten.

\subsection{Diffusion coefficients}

MacNevin and Moorhead ${ }^{15)}$ calculated the diffusion coefficient of $\mathrm{Ga}$ (III) in $0.50 \mathrm{mM} \mathrm{Ga}\left(\mathrm{NO}_{3}\right)_{3}$ and $7.5 \mathrm{M}$ KSCN solution from the diffusion current constant. The value was $0.84 \times 10^{-6} \mathrm{~cm}^{2} / \mathrm{s}$ with the assumption that $\mathrm{n}$ is 3 . After that Moorhead and Furman ${ }^{87)}$ obtained new diffusion coefficient for $0.3 \sim 2.5 \mathrm{mM}$ $\mathrm{Ga}(\mathrm{III})$ in 7.5 F KSCN from the linear relationship between the square root of the transition time $\left(\tau^{1 / 2}\right)$ and gallium concentration using chronopotentiometry as Eq. (40):

$$
\tau^{1 / 2}=\frac{\pi^{1 / 2} \mathrm{nFD}^{1 / 2} \mathrm{C}_{\mathrm{o}}}{2 \mathrm{i}_{\mathrm{o}}}
$$

At a current density of $0.231 \mathrm{~mA}$ the diffusion coefficient was $2.04 \times 10^{-6} \mathrm{~cm}^{2} / \mathrm{s}$, which was 2.3 times larger than previously reported value. ${ }^{15)}$ Moorhead and Frame $^{49)}$ applied the modified Ilkovic equation [Eq. $(41)]^{88)}$ to obtain diffusion coefficient of $\mathrm{Ga}$ (III) because of nonlinear plots of both $i_{d}$ and $\tau^{1 / 2}$ vs. [Ga(III)] below $0.3 \mathrm{mM} \mathrm{Ga(III):}$

$$
\mathrm{i}_{\mathrm{d}}=607 \mathrm{nCD} \mathrm{D}^{1 / 2} \mathrm{~m}^{2 / 3} \mathrm{t}^{1 / 6}\left(1+\frac{39 \mathrm{D}^{1 / 2} \mathrm{t}^{1 / 6}}{\mathrm{~m}^{1 / 3}}\right)
$$

The $\mathrm{Ga}(\mathrm{III})$ diffusion coefficient was calculated to be $3.06 \times 10^{-6} \mathrm{~cm}^{2} / \mathrm{s}$ in $0.1 \mathrm{M} \mathrm{NaSCN}$ and $6.0 \mathrm{M}$ $\mathrm{NaClO}_{4}$ at $30^{\circ} \mathrm{C}$. Recalculation of previous data for 7.5 $\mathrm{M} \mathrm{KSCN}^{15,87)}$ using the same equation gave $\mathrm{D}=$ $2.84 \times 10^{-6} \mathrm{~cm}^{2} / \mathrm{s}$ and $\mathrm{D}=2.20 \times 10^{-6} \mathrm{~cm}^{2} / \mathrm{s}$ at $30^{\circ} \mathrm{C}$. Kariuki and Dewald ${ }^{89)}$ obtained the diffusion coefficient of $\mathrm{Ga}(\mathrm{III})$ in $\mathrm{KNO}_{3}$ and $\mathrm{KCl}$ through Ilkovic equation for maximum currents as followed:

$$
\left(\mathrm{i}_{\mathrm{d}}\right)_{\max }=708 \mathrm{nCD}^{1 / 2} \mathrm{~m}^{2 / 3} \mathrm{t}^{1 / 6}
$$

The diffusion coefficient values of $\mathrm{Ga}$ (III) obtained in $0.04 \mathrm{M} \mathrm{KNO}_{3}$ was $1.88 \times 10^{-6} \mathrm{~cm}^{2} / \mathrm{s}$. Flamini et $a l .{ }^{69)}$ recorded potentiostatic transient on a vitreous carbon surface in $0.5 \mathrm{M} \mathrm{Cl}^{-}, \mathrm{pH} 2.5$ containing $0.01 \mathrm{M}$ $\mathrm{Ga}^{3+}$ during the $\mathrm{Ga}$ deposition process. The authors obtained the diffusion coefficients from the currenttime response which is known as the Cottrell equation:

$$
\mathrm{i}(\mathrm{t})=\mathrm{i}_{\mathrm{d}}(\mathrm{t})=\frac{\mathrm{nFAD} \mathrm{D}^{1 / 2} \mathrm{C}}{\pi^{1 / 2} \mathrm{t}^{1 / 2}}
$$

The mean value of the diffusion coefficient obtained from the slope of $\mathrm{i}$ vs. $\mathrm{t}^{-1 / 2}$ lines was $1.92 \times 10^{-5} \mathrm{~cm}^{2} / \mathrm{s}$. The diffusion coefficient values obtained under different conditions are listed in Table 2. 
Table 2. Diffusion coefficient values of Ga(III) in aqueous solutions obtained under different conditions and from different equations

\begin{tabular}{|c|c|c|c|c|c|c|}
\hline Conc. of $\mathrm{Ga}(\mathrm{III})$ & Electrolyte & $\mathrm{pH}$ & Temperature $\left({ }^{\circ} \mathrm{C}\right)$ & $\mathrm{D} \times 10^{-6}\left(\mathrm{~cm}^{2} / \mathrm{s}\right)$ & Applied Eq. & Reference \\
\hline $0.50 \mathrm{mM}$ & $7.5 \mathrm{M} \mathrm{KSCN}$ & 3.56 & 25 & 0.84 & Eq. 44 & 15 \\
\hline $0.50 \mathrm{mM}$ & $7.5 \mathrm{M} \mathrm{KSCN}$ & 3.56 & 30 & 2.84 & Eq. 41 & 49 \\
\hline $0.3 \mathrm{mM} \leq \mathrm{C}_{\mathrm{Ga}(\mathrm{III})} \leq 2.5 \mathrm{mM}$ & $7.5 \mathrm{~F} \mathrm{KSCN}$ & 3.2 & 25 & 2.0 (mean value) & Eq. 40 & 87 \\
\hline $0.3 \mathrm{mM} \leq \mathrm{C}_{\mathrm{Ga}(\mathrm{III})} \leq 2.5 \mathrm{mM}$ & $7.5 \mathrm{~F} \mathrm{KSCN}$ & 3.2 & 30 & 2.2 & Eq. 41 & 49 \\
\hline $0.01 \mathrm{mM} \leq \mathrm{C}_{\mathrm{Ga}(\mathrm{IIII})} \leq 5.0 \mathrm{mM}$ & $\begin{array}{c}0.1 \mathrm{M} \mathrm{NaSCN}^{\&} \\
6.0 \mathrm{M} \mathrm{NaClO}_{4}\end{array}$ & 1 & 30 & 3.06 & Eq. 41 & 49 \\
\hline $0.5 \mathrm{mM}$ & $0.04 \mathrm{M} \mathrm{KNO}_{3}$ & 3.52 & 25 & 1.88 & Eq. 42 & 89 \\
\hline $0.5 \mathrm{mM}$ & $0.2 \mathrm{M} \mathrm{KNO}_{3}$ & 3.52 & 25 & 2.27 & Eq. 42 & 89 \\
\hline $0.5 \mathrm{mM}$ & $0.04 \mathrm{M} \mathrm{KCl}$ & 3.51 & 25 & 1.74 & Eq. 42 & 89 \\
\hline $0.5 \mathrm{mM}$ & $0.2 \mathrm{M} \mathrm{KCl}$ & 3.51 & 25 & 1.90 & Eq. 42 & 89 \\
\hline $0.01 \mathrm{M}$ & $0.5 \mathrm{M} \mathrm{NaCl}$ & 2.5 & - & 19.2 (mean value) & Eq. 43 & 69 \\
\hline
\end{tabular}

Sharma and Gupta ${ }^{52,85)}$ calculated the diffusion coefficient of Ga(III)- DL $\alpha$-alanine ${ }^{85)}$ and Ga(III)- Lglutamine $^{52)}$ from Ilkovic equation for average currents at different concentration of amino acid and different temperature. The data are listed in Table 1.

$$
\mathrm{i}_{\mathrm{d}}=607 \mathrm{nCD}^{1 / 2} \mathrm{~m}^{2 / 3} \mathrm{t}^{1 / 6}
$$

In the case of $\mathrm{Ga}(\mathrm{III})$ - L-glutamine, ${ }^{52)} \mathrm{D}$ was $9.41 \times 10^{-3} \mathrm{~cm}^{2} / \mathrm{s}$ in $0.01 \mathrm{M} \mathrm{L}$-glutamine at $30^{\circ} \mathrm{C}$. The diffusion coefficient decreased with increase in concentration of amino acid. Chen et al. ${ }^{55)}$ determined the diffusion coefficients of $\mathrm{Ga}$ (III) and $\mathrm{Ga}(\mathrm{I})$ in $\mathrm{AlCl}_{3}$ MIIC melt at $30^{\circ} \mathrm{C}$. The diffusion coefficients for $\mathrm{Ga}(\mathrm{III})$ and $\mathrm{Ga}(\mathrm{I})$ were $2.28 \times 10^{-7}$ and $9.12 \times 10^{-7}$ $\mathrm{cm}^{2} / \mathrm{s}$.

\section{Electroanalytical Methods for Determi- nation of Gallium}

In trace analysis of gallium, anodic stripping voltammetry (ASV) and adsorptive cathodic stripping voltammetry (AdCSV) are mainly used. ASV is based on previous electrolytical accumulation of the metal ion to be determined on the working electrode, followed by voltammetric dissolution of reduced metal on the electrode. In AdCSV, preconcentration of the metal is achieved by means of adsorption of a surface-active metal complex with ligands on a mercury electrode, prior to reduction of the accumulated material. ${ }^{90,91)}$

\subsection{Anodic stripping voltammetry of gallium}

The anodic stripping determination of gallium is based on the formation of its amalgam. Moorhead et $a l$. suggested that at room temperature the reversible gallium electrode reaction is synergetically controlled by two factors: (1) the presence of a complexing agent and (2) the presence of a state of high ionic strength $(\mathrm{J})$ in the cell. ${ }^{16,46)}$ Good results of ASV were achieved in solutions containing thiocyanate or salicylate..$^{7,16,46,92)}$

The determination of gallium traces was carried out on the hanging drop mercury electrode in solutions of low ionic strength and in absence of complexing agents by Udisti and Piccardi. ${ }^{92)}$ A constant value of anodic peak current was obtained in the presence of $0.02 \mathrm{M} \mathrm{NaClO}_{4}$ and $0.005 \mathrm{M} \mathrm{CH}_{3} \mathrm{COOH}$ at the $\mathrm{pH}$ of 3.2 for the deposition potential of $-1.25 \mathrm{~V}$ (vs. SCE). In this measurement a limit of detection (LOD) of Ga was $4 \mathrm{ng} \mathrm{L}^{-1}$. Using salicylate, a weak complexing agent the stable solutions were also obtained at higher $\mathrm{pH}$ of 4.6. The authors reported that the sensitivity obtained through differential pulse voltammetry was better than that of phase selective voltammetry proposed by Moorhead. ${ }^{7,93)}$ Cofre and Brinck ${ }^{94)}$ investigated the interference of zinc during the determination of gallium in the $0.5 \mathrm{M} \mathrm{NaSCN}-4.2 \mathrm{M} \mathrm{NaClO}_{4}$ solution containing gallium and zinc by anodic stripping square-wave voltammetry. As a deposition potential, $E_{d}$, of $-1.100 \mathrm{~V}$ was used, the simultaneous deposition of $\mathrm{Zn}$ and $\mathrm{Ga}$ occurred and as $\mathrm{E}_{\mathrm{d}}$ was $-1.000 \mathrm{~V}, \mathrm{Ga}-\mathrm{Zn}$ $(3: 2)$ intermetallic compound was deposited. The $\mathrm{Zn}$ interference could be eliminated by addition of $\mathrm{Sb}$ (III) as following:

$$
\mathrm{Zn}_{2} \mathrm{Ga}_{3}+2 \mathrm{Sb} \rightarrow 2 \mathrm{ZnSb}+3 \mathrm{Ga}
$$

East and Cofre ${ }^{95)}$ also studied the determination of trace concentration of gallium in non aqueous solution. The determination was carried out by squarewave voltammetry anodic stripping based on the elec- 
trocatalytic action of 2,2'-bipyridine (DIPY) in dimethylsulfoxide (DMSO) solution. $\mathrm{Ga}$ (III) concentrations down to $2 \times 10^{-8} \mathrm{M}$ could be determined with the DIPY-DMSO method. The concentration of DIPY was only $1.5 \times 10^{-3} \mathrm{M}$, and the concentration of supporting electrolyte, tetraethylammonium perchlorate (TEAP), was $0.1 \mathrm{M}$. The DIPY-DMSO method could be applied to the determination of gallium content in rock mineral samples and the comparison with the $\mathrm{NaSCN}$ based method proved that equally good results could be obtained with the DIPY-DMSO. The great advantage was introducing much less impurities as the supporting electrolyte and electrocatalyst from reagents.

Piech and $\mathrm{Bas}^{6)}$ applied cyclic renewable silver amalgam film electrode $(\mathrm{Hg}(\mathrm{Ag}) \mathrm{FE})$ for determination of gallium (III) using differential pulse anodic stripping voltammetry. The measurement was performed in a solution of $0.01 \mathrm{M} \mathrm{KSCN}$ solution of $\mathrm{pH}$ 3.05. The calibration graph was linear from $5 \mathrm{nM}$ to 80 $\mathrm{nM}$ for an accumulation time of $60 \mathrm{~s}$. For a $\mathrm{Hg}(\mathrm{Ag}) \mathrm{FE}$ with a surface area of $9.9 \mathrm{~mm}^{2}$, an accumulation potential of $-1.05 \mathrm{~V}$ (vs. $\mathrm{Ag} / \mathrm{AgCl}$ ), and an accumulation time of $120 \mathrm{~s}$, LOD was as low as $1.5 \mathrm{nM}$ $\left(=0.1 \mu \mathrm{g} \mathrm{L}^{-1}\right)$. One of challenges to develop non-mercury based electrode for the selective and sensitive detection of $\mathrm{Ga}(\mathrm{III})$ was the introduction of bismuth film electrode (BiFE) on glassy carbon by Kamat et $a .^{5)}$ This study demonstrated the scope of employing the square wave anodic stripping voltammetry on BiFE in a buffer solution of $\mathrm{pH} 4.6$ for the detection of $\mathrm{Ga}(\mathrm{III})$. The performance of BiFE was also studied for interferences of $\mathrm{Zn}(\mathrm{II}), \mathrm{Cd}(\mathrm{II}), \mathrm{Tl}(\mathrm{I})$, and $\mathrm{Cu}(\mathrm{II})$ ions. A good linear dynamic range $\left(\mathrm{R}^{2}=0.996\right)$ was obtained in the concentration range of $20-100 \mathrm{mg} / \mathrm{L}$ with LOD of $6.6 \mathrm{mg} / \mathrm{L}(\mathrm{S} / \mathrm{N}=3)$ for $\mathrm{Ga}(\mathrm{III})$. The determination of $\mathrm{Ga}(\mathrm{III})$ on $\mathrm{BiFE}$ in presence of $20 \mathrm{mg} / \mathrm{L}$ each of the interfering ions, $\mathrm{Zn}(\mathrm{II}), \mathrm{Cd}(\mathrm{II})$, and $\mathrm{Tl}(\mathrm{I})$, showed second order polynomial dependency in the concentration range of $20-140 \mathrm{mg} / \mathrm{L}$ and LOD of $2.3 \mathrm{mg} / \mathrm{L}$. The performance of BiFE was found to be better than conventional mercury film electrode.

Medvecký L' and Brianèin ${ }^{96)}$ studied the possibilities of simultaneous determination of In and Ga by square wave anodic stripping voltammetry on $\mathrm{Hg}, \mathrm{Bi}$, and $\mathrm{HgBi}$ thin film electrode (HgBi TFE) generated in situ on glassy carbon electrode. The relationship between the peak height of $\mathrm{Ga}$ and its concentration in a presence of In ions showed a mutual Ga-In influence in the reduction process on $\mathrm{HgBi}$ TFE. The presence of indium is acting on the Ga deposition in an inhibitive way. It was found that indium competed with bismuth and gallium with mercury for surface sites on glassy carbon and $\mathrm{HgBi}$ TFE was suitable for simultaneous determination of In and Ga from their results.

Sharma et al $^{97)}$ carried out the quantification of gallium at milligram levels from the quantity of charge obtained in the oxidation step. This approach was possible because $\mathrm{Ga}(\mathrm{III}) / \mathrm{Ga}$ electrode process became closer to reversible in the medium of $4 \mathrm{M} \mathrm{NaClO}_{4}$ and $0.5 \mathrm{M} \mathrm{NaSCN}$, at static mercury drop electrode. It was observed that the amount of $\mathrm{Ga}(\mathrm{III})$ reduced at the potential of $-0.95 \mathrm{~V}$ vs. SCE was quantitatively oxidized back to $\mathrm{Ga}(\mathrm{III})$ at $-0.60 \mathrm{~V}$ and the oxidation of Ga metal was a much faster electrode process as compared to the reduction of $\mathrm{Ga}$ (III) to Ga.

\subsection{Adsorptive cathodic stripping voltammetry of gallium}

Anodic stripping voltammetry is a potentially attractive approach for trace quantification of gallium because gallium on mercury is soluble and its reversible reduction process in the presence of some ligand is possible. However, the anodic response of gallium in acidic media is masked by hydrogen evolution and the accuracy of measurement is adversely affected by the formation of intermetallic compounds between gallium and zinc, copper, or nickel. ${ }^{98,99)}$ Therefore authors developed an alternative stripping approach for trace quantitation of gallium. Adsorptive cathodic stripping voltammetry (AdCSV) had been applied to the detection of metals such as $\mathrm{Co}, \mathrm{Ni}, \mathrm{Cu}, \mathrm{Mo}, \mathrm{U}$ and V. In AdCSV, ligands, such as dimethylglyoxime, ${ }^{100)}$ catechol, ${ }^{101,102)}$ cupferron, ${ }^{103)}$ and chloroanilic acid ${ }^{104)}$ were chosen for complexation of gallium.

Wang and Zadii $^{98)}$ performed trace quantification of gallium using adsorptive cathodic stripping voltammetry. Concentration of gallium was determined by linearsweep voltammetry after adsorptive preconcentration of the gallium-solochrome violet RS (sodium 4-hydroxy3-[(2Z)-2-(2-oxonaphthalen-1-ylidene) hydrazinyl] benzenesulfonate) chelate on the hanging mercury drop electrode in an acetate buffer solution of $\mathrm{pH} 4.8$. For the preconcentration at $-0.4 \mathrm{~V}$ and for $2 \mathrm{~min}$, the detection limit was $0.08 \mathrm{mg} \mathrm{L}^{-1}$. Qu and $\mathrm{Jin}^{105)}$ investigated the behaviour of the $\mathrm{Ga}$ (III) complex with morin (2-(2,4-dihydroxyphenyl)-3,5,7-trihydroxychromen4-one) in HOAc-NaOAc at a mercury electrode was 


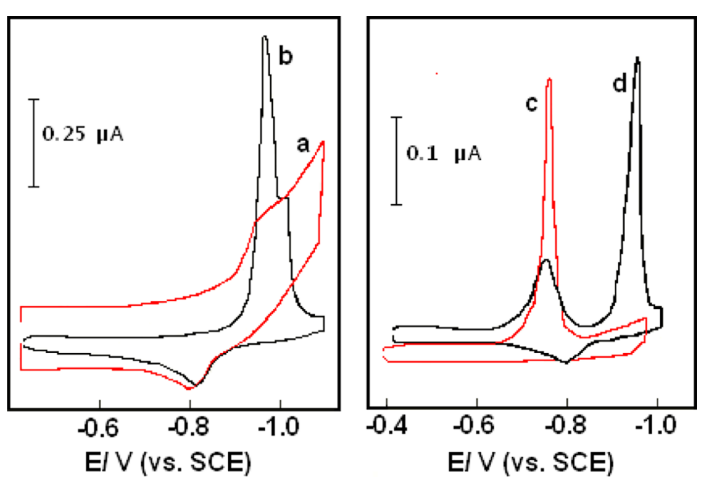

Fig. 10. Cyclic adsorption voltammograms of (a) $3.3 \times 10^{-}$ ${ }^{6} \mathrm{M} \mathrm{Ga}(\mathrm{III})$, (c) $2.5 \times 10^{-6} \mathrm{M} \mathrm{SAF}$, and (b), (d) Ga(III) complex with SAF (b, $3.3 \times 10^{-6} \mathrm{M} \mathrm{Ga}(\mathrm{III})$ and $2.5 \times 10^{-6}$ M SAF; d, $3.3 \times 10^{-7} \mathrm{M} \mathrm{Ga}(\mathrm{III})$ and $\left.2.5 \times 10^{-6} \mathrm{M} \mathrm{SAF}\right)$ in $0.2 \mathrm{M}$ potassium hydrogen phthalate solutions of $\mathrm{pH} 3$. Scan rates are $50 \mathrm{mV} / \mathrm{s}$ [modified from Fig. 5 of ref. 106].

investigated. Gallium with morin formed a complex of $\mathrm{GaL}_{3}$. The optimum concentration of morin was $1 \times 10^{-6} \mathrm{M}$ and the preconcentration step was carried out at the potential of $-0.65 \mathrm{~V}$ (vs. $\mathrm{Ag} / \mathrm{AgCl}$ ) for 2 $\mathrm{min}$. The adsorption phenomena were observed by linear-sweep voltammetry and drop-time curves. Under optimum conditions, the limit of detection and the linear range of the 1.5 th-order derivative were $4 \times 10^{-10}$ $\mathrm{M}$ and from $1 \times 10^{-9}$ to $1 \times 10^{-7} \mathrm{M}$, respectively. Zhang et al. ${ }^{106)}$ described an AdCSV of the galliumsalicyl fluorone (SAF) at a hanging mercury dropping electrode. They measured the cyclic adsorption voltammograms of Ga-SAF system as Fig. 10. The reduction of $\mathrm{Ga}(\mathrm{III}) / \mathrm{Ga}(0)(\mathrm{Hg})$ was shown at a potential of $-1.0 \mathrm{~V}$; the oxidation of $\mathrm{Ga}(0)(\mathrm{Hg}) / \mathrm{Ga}$ (III) was shown at $-0.80 \mathrm{~V}$. For Ga-SAF complex, there was only one adsorptive reduction peak $\left(\mathrm{E}_{\mathrm{p}}=-0.93 \mathrm{~V}\right)$ and no corresponding oxidation peak. The reduction peak height of the complex was proportional to the concentration of $\mathrm{Ga}$ (III) in the range of $1.5 \times 10^{-9}$ to $6.0 \times 10^{-7} \mathrm{M}$, LOD was $1.0 \times 10^{-9} \mathrm{M}$. González et al.$^{99)}$ developed a procedure for the determination of gallium by differential pulse adsorptive stripping voltammetry, using different complexing agents (ammonium pyrrolidine dithiocarbamate, pyrocatechol violet, and diethyldithiocarbamate). For the use of diethyldithiocarbamate as a complexing agent in an acetate buffer, the lowest detection limit was obtained, which was $1.0 \times 10^{-9}$ M. Piech ${ }^{107)}$ presented an AdCSV method on the cyclic renewable mercury film silver based electrode $(\mathrm{Hg}(\mathrm{Ag}) \mathrm{FE})$ for the determination of trace
gallium(III) based on the adsorption of gallium(III)catechol complex. For a $\mathrm{Hg}(\mathrm{Ag}) \mathrm{FE}$ with a surface area of $9.7 \mathrm{~mm}^{2}$ and a preconcentration time of $90 \mathrm{~s}$, LOD was as low as $0.1 \mathrm{nM}\left(7 \mathrm{ng} \mathrm{L}^{-1}\right)$. The proposed method was also applied to the simultaneous recovery of $\mathrm{Ga}(\mathrm{III})$ and $\mathrm{Ge}(\mathrm{IV})$ from spiked water and sediment samples. ${ }^{108)}$ The detection limit for a preconcentration time of $60 \mathrm{~s}$ was as low as $25 \mathrm{ng} \mathrm{L}^{-1}$ for gallium and $58 \mathrm{ng} \mathrm{L}^{-1}$ for germanium. Pysarevska et al. ${ }^{109)}$ investigated the voltammetric behaviour of $\mathrm{Ga}$ (III) complexes with o,o'-dihydroxysubstituted azo dyes (eriochrome red B, eriochrome black T, calcon, and kalces) on a dropping mercury electrode using cyclic linear sweep voltammetry. The methods using Ga(III)azo dyes complexes were tested on the determination of gallium in intermetallic compounds of $\mathrm{Zn}-\mathrm{Ga}, \mathrm{Sm}$ $\mathrm{Ga}$, and in $\mathrm{Gd}_{3} \mathrm{Sc}_{2} \mathrm{Ga}_{3} \mathrm{O}$ luminophore. The lowest value of $2 \times 10^{-7} \mathrm{M}$ was obtained using eriochrome red $\mathrm{B}$.

\subsection{Ion selective electrode for gallium determina- tion}

Mohamed ${ }^{110)}$ tried to develop selective electrodes for $\mathrm{Ga}(\mathrm{III})$ determination via potentiometry using the macrocycle ligand 2,9-dimethyl-4,11-diphenyl1,5,8,12-tetraazacyclotetradeca-1,4,7,11-tetraene (DDTCT). The poly(vinylchloride)-based membrane electrode of DDTCT with dibutyl phthalate as a placiticizing solvent mediator and tetraphenyl borate as an anion excluder showed the best performance. The working concentration range of the electrode was $1.45 \times 10^{-6}$ to $0.1 \mathrm{M}$. Abbaspour et al. ${ }^{111)}$ demonstrated the multi-walled carbon nanotube (MWCNT) composite coated platinum electrode for the electrochemical detection of gallium ion. In order to increase the sensitibity they applied the MWCNT composite poly(vinylchloride) coated platinum electrode with 7(2-hydroxy-5-methoxybenzyl)-5,6,7,8,9,10-hexahydro-2 $\mathrm{H}$ benzo $[\mathrm{b}][1,4,7,10,13]$ dioxa triaza cyclopentadecine-3,11(4H,12H)-dione as an ionophore and dibutyl sebacate as a placiticizing solvent mediator. The sensor showed linear response in wide range concentrations of $7.9 \times 10^{-7}$ to $3.2 \times 10^{-2} \mathrm{M}$. The detection limit of this electrode was $5.2 \times 10^{-7} \mathrm{M}$ of $\mathrm{Ga}\left(\mathrm{NO}_{3}\right)_{3}$.

\section{Conclusions}

It was confirmed the reversible gallium reduction was attained by the addition of $\mathrm{N}_{3}^{-}$and $\mathrm{SCN}^{-}$in acidic 
solution. However, azide anion promoted the reversible reduction of $\mathrm{Ga}^{3+}$ ions unassisted by high ionic strength or elevated temperature unlike $\mathrm{SCN}^{-}$. The redox reactions of $\mathrm{Ga}(\mathrm{III}) / \mathrm{Ga}(\mathrm{I})$ and $\mathrm{Ga}(\mathrm{I}) / \mathrm{Ga}(0)$ couples on tungsten electrodes in $60.0 / 40.0 \mathrm{~mol} \%$ aluminum chloride and 1-methyl-3-ethylimidazolium chloride molten salt were identified. The heterogeneous rate constants for the reduction of $\mathrm{Ga}(\mathrm{III})$-complexes with DL a-alanine and L-glutamine were obtained. The reduction of $\mathrm{Ga}$ (III)-amino acid complex was increasingly irreversible with increases in concentrations of the amino acid as a ligand. The anodic oxidation of gallium metal gave rise to passivating layers in both alkaline and acidic solutions. In low concentration of alkali, $\mathrm{Ga}(\mathrm{OH})_{3}$ as passivating layers on a solid gallium electrode was produced and in an alkali solution of high concentration, $\mathrm{GaO}(\mathrm{OH})$ barrier layers were formed. In an acidic solution, coatings, as salts of $\mathrm{Ga}^{3+}$ with anions or $\mathrm{H}_{2} \mathrm{O}$ grew on a gallium surface via an adsorbed oxidation product, $\mathrm{GaOH}_{\mathrm{ads}}$, and soluble $\mathrm{Ga}^{3+}$ species, $\mathrm{Ga}(\mathrm{OH})_{2}{ }^{+}$. For trace analysis of gallium, anodic stripping voltammetry (ASV) and adsorptive cathodic stripping voltammetry (AdCSV) were mainly used. Several attempts in stripping voltammetries have been made in order to better analyze. The interference of $\mathrm{Zn}$ observed in the gallium determination could be eliminated by addition of $\mathrm{Sb}(\mathrm{III})$. The uses of cyclic renewable silver amalgam film electrode $(\mathrm{Hg}(\mathrm{Ag}) \mathrm{FE})$ and BiFE instead of conventional mercury electrode for the ASV showed better results. AdCSV with various complexing agents was introduced to complement the disadvantages of ASV. For the AdCSV method based on the adsorption of gallium(III)-catechol complexes on the cyclic renewable $\mathrm{Hg}(\mathrm{Ag}) \mathrm{FE}$, the detection limit was as low as $0.1 \mathrm{nM}\left(7 \mathrm{ng} \mathrm{L}^{-1}\right)$.

\section{Acknowledgements}

This work was financially supported by National Research Foundation of Korea (2010-0029164)

\section{References}

1. R. R. Moskalyk, Miner. Eng., 16, 921 (2003).

2. A. P. Thompson, "Gallium", C.A. Hampel (ed.) Rare metals handbook, Chapman and Hall Ltd, London, pp 178-187 (1961).

3. B. W. Jaskula, "Gallium", United State Geological Survey (USGS) Mineral Commodity Summaries, January, (2012).
4. A. R. Despic, D. M. Drazic, M. M. Purenovic, and N. Cikovic, J. Appl. Electrochem., 6, 527 (1976).

5. J. V. Kamat, S. K. Guin, J. S. Pillai, and S. K. Aggarwal, Talanta, 86, 256 (2011).

6. R. Piech and B. Bas, Int. J. Envir. Anal. Chem., 91, 410 (2011).

7. E. D. Moorhead and P. H. Davis, Anal. Chem., 47, 622 (1975).

8. T. I. Popova, I. A. Bagotskaya, and E. D. Moorhead, "Gallium", A.J. Bard (ed.) Encyclopedia of electrochemistry of the elements, vol. 8. Marcel Dekker Inc, New York, pp 207-262 (1978).

9. M. Pourbaix, Atlas of electrochemical equilibria in aqueous solutions, NACE International, pp 428-435 (1974).

10. J. D. Corbett and R.K. Mcmullan, J. Am. Chem. Soc., 77, 4217 (1955).

11. P. Sipos, T. Megyes, and O. Berkesi, J. Solution Chem., 37, 1411 (2008).

12. U. Anders and J. A. Plambeck, Can. J. Chem., 47, 3055 (1969).

13. T. W. Richards and S. Boyer, J. Am. Chem. Soc., 43, 274. (1921).

14. W. M. Saltman and N. H. Nachtriev, J. Electrochem. Soc., 100, 126. (1953).

15. W. M. MacNevin and E. D. Moorhead, J. Am. Chem. Soc., 81, 6382 (1959).

16. E. D. Moorhead, J. Am. Chem. Soc., 87, 2503 (1965).

17. S. G. Christov and S. Rajceva, Z. Elektrochem., 66, 484 (1962).

18. E. N. Potapova and I. A. Bagotskaya, Elektrokhimiya, 5, 1007 (1969).

19. I. A. Bagotskaya and E. N. Potapova, Elektrokhimiya, 6, 855 (1970).

20. A. Frumkin and A. Gorodetskaya, Z. Phys. Chem., 136, 215 (1928).

21. D. C. Grahame, Anal. Chem., 30, 1736 (1958).

22. N. B. Grigoryev, S. A. Fateev, and I. A. Bagotskaya, Elektrokhimiya, 8, 311 (1972).

23. A. J. Gokhshtein, Elektrokhimiya, 7, 3 (1971).

24. G. Wolf, Z. Phys. Chem., 223, 249 (1963).

25. K. Schwabe, Z. Phys. Chem., 211, 170 (1959).

26. O. Stelling, Z. Elektrochem., 41, 712 (1935).

27. S. Rajceva and L. Andreeva, C.R. Acad. Bulg. Sci., 19, 925 (1966).

28. F. F. Faizullin and E. N. Nikitin, Elektrokhimiya, 2, 112 (1966).

29. F. F. Faizullin, E. N. Nikitin, N. N. Gudina, and S. M. Yamolotdinov, Issled. Elektrokhim. Kazan, 1969 (2), 117 (1969).

30. T. I. Lezhava and A. T. Vagramyan, Elektrokhimiya, 1, 321 (1965).

31. D. Belaschk, Z. Phys. Chem., 234, 258 (1967).

32. T. I. Popova, N. A. Simonova, Z. J. Moyseeva, and N. G. Bardina, Elektrokhimiya, 6, 706 (1970).

33. R. D. Armstrong, W. P. Race, and H. R. Thirsk, J. 
Electroanal. Chem., 31, 405 (1971).

34. T. Hurlen, T. Valand, and G. Lunde, Electrochim. Acta, $\mathbf{9}$, 1433 (1964).

35. J. D. Corbett, J. Electrochem. Soc., 109, 1214 (1962).

36. T. Hurlen, Electrochim. Acta, 9, 1449 (1964).

37. I. A. Bagotskaya and N. M. Genkina, Elektrokhimiya, 3, 1485 (1967).

38. S. A. Levitskaya, M. S. Polagutina, and A. I. Zebreva, Usp. Sov. Polagr., 1972, 37 (1972).

39. I. G. Vasil'eva and A. I. Zebreva, Zh. Fiz. Khim., 38, 1774 (1964).

40. I. A. Bagotskaya and D. K. Durmanov, Elektrokhimiya, 4, 1414 (1968)

41. J. O’M. Bockris and M. Enyo, J. Electrochem. Soc., 109, 48 (1962).

42. V. M. Kochegarov and T. P. Lomakina, Zh. Fiz. Khim., 38, 2703 (1964).

43. I. G. Vasil'eva and A. I. Zebreva, Elektrokhimiya, 1, 146 (1965).

44. Y. Chung and C-W Lee, J. Electrochem. Sci. Tech., 3, 1 (2012).

45. V. S. Saji and C-W Lee, RSC $A d v$., Accepted (2013)

46. E. D. Moorhead and G. M. Frame II, J. Electroanal. Chem. Interfacial Electrochem., 18, 197 (1968).

47. C. A. Stoll, G. M. Frame II, and E. D. Moorhead, Anal. Lett., 1, 861 (1968).

48. A. Iwasinska, Z. Stojek, and Z. Kublik, J. Electroanal. Chem., 179, 141 (1984).

49. E. D. Moorhead and G. M. Frame II, Anal. Chem., 40, 280 (1968).

50. H. S. Sharma, T. K. Bhardwaj, P. C. Jain, and S. K. Aggarwal, Ind. J. Chem., 45A, 643 (2006).

51. E. D. Moorhead and T. S. Robison, Anal. Chem., 64, 833 (1992).

52. V. Sharma and K. D. Gupta, Monatsh Chem., 142, 481 (2011).

53. L. F. Kozin and A. V. Gaidin, Russ. J. Appl. Chem., 82, 406 (2009).

54. P. Cofre, G. East, and C. Aguirre, Talanta, 39, 621 (1992).

55. P. Y. Chen, Y. F. Lin, and I. W. Sun, J. Electrochem. Soc., 146, 3290 (1999).

56. V. V. Smolenski, A. A. Khokhrykov, A. L. Bove, and A. G. Osipenko, AIP Conf. Proc., 673, 321 (2003).

57. L. H. S. Gasparotto, N. Borisenko, O. Höfft, R. AlSalman, W. Maus-Friedrichs, N. Bocchi, and S. Zein El Abedin, and F. Endres, Electrochim. Acta, 55, 218-226 (2009).

58. E. V. Nikitin, S. V. Kuzovenko, and F. F. Faizullin, Sov. Electrochem., 7, 1062 (1971).

59. R. S. Perkins, J. Electroanal. Chem., 101, 47 (1979).

60. N. P. Selekhova, N. A. Lyubimova, and D. I. Leikis, Elektrokhimiya, 8, 721 (1972).

61. A. Varadharaj and G. Prabhakara Rao, J. Electroanal. Chem., 138, 189 (1982).

62. A. Varadharaj and G. Prabhakara Rao, Bull. Electrochem.,
6, 482 (1990).

63. A. Varadharaj and G. Prabhakara Rao, Proc. Indian Acad. Sci. (Chem. Sci.), 102, 177 (1990).

64. R. S. Perkins, J. Electrochem. Soc., 119, 713 (1972).

65. V. N. Korshunov, Russ. J. Eledctrochem., 31, 1036 (1995).

66. V. N. Korshunov, Russ. J. Electrochem., 33, 919 (1997).

67. A. Tsvetanova, E. I. Sokolova, and S. N. Raicheva, Soviet Electrochem., 15, 185 (1979).

68. Z. G. Gasanly and T. L. Guseinzaden, Russ. J. Appl. Chem., 81, 1565 (2008).

69. D. O. Flamini, S. B. Saidman, and J. B. Bessone, J. Appl. Electrochem., 37, 467 (2007).

70. M. Al Zoubi, R. Al-Salman, S. Z. El Abedin, Y. Li, and F. Endres, ChemPhysChem, 12, 2751 (2011).

71. L. F. Kozin, T. V. Popova, A. K. Dzhasymbekov, and R. G. Sarmurzina, Elektrokhimiya, 17, 655 (1981).

72. A. Varadharaj and G. Prabhakara Rao, J. Appl. Electrochem., 16, 929 (1986).

73. R. Dorin and E. J. Frazer, J. Appl. Electrochem., 18, 134 (1988).

74. A. Varadharaj, L. Swati, J. A. M. Abdulkader, N. Sathaiyan, and R. Srinivasan, Bull. Electrochem., 4, 385 (1988).

75. A. Varadharaj, R. Srinivasan, and G. Prabhakara Rao, J. Appl. Electrochem., 19, 61 (1989).

76. R. C. Paciej, G. L. Cahen, G. E. Stoner, and E. Gileadi, J. Electrochem. Soc., 132, 1307 (1985).

77. F. Paolucci, G. Mengoli, and M. M. Musiani, J. Appl. Electrochem., 20, 868 (1990).

78. J. Kois, M. Ganchev, M. Kaelin, S. Bereznev, E. Tzvetkova, O. Volobujeva, N. Stratieva, and A. N. Tiwari, Thin Solid Films, 516, 5948 (2008).

79. Y. Lai, F. Liu, Z. Zhang, J. Liu, Y. Li, S. Kuang, J. Li, and Y. Liu, Electrochim. Acta, 54, 3004 (2009).

80. Y. Lai, J. Liu, J. Yang, B. Wang, F. Liu, Z. Zhang, J. Li, and Y. Liu, J. Electrochem. Soc., 158, D704 (2011).

81. D. Iselt, U. Gaitzsch, S. Oswald, S. Fähler, L. Schultz, and H. Schlörb, Electrochim. Acta, 56, 5178 (2011).

82. S. M. Reddy, J. J. Park, S-M Na, M. M. Magableh, A. B. Flatau, and B.J.H. Stadler, Adv. Funct. Mater., 21, 4677 (2011).

83. M. K. Carpenter and M. W. Verbrugge, J. Electrochem. Soc., 137, 123 (1990).

84. E. D. Moorhead and G. M. Frame II, J. Phys. Chem., 72, 3684 (1968).

85. V. Sharma and K. D. Gupta, Asian J. Chem., 16, 1398 (2004).

86. A. J. Bard and L. R. Faulkner, Chap. 5 and 8, Electrochemical Methods: Fundamentals and Applications, John Wiley \& Sons, New York (1980).

87. E. D. Moorhead and N. H. Furman, Anal. Chem., 32, 1507 (1960).

88. J. J. Lingane and B. A. Loveridge, J. Am. Chem. Soc., 72, 438 (1968).

89. S. Kariuki and H. Dewald, Electroanalysis, 9, 231 
(1997).

90. R. Kalvoda and M. Kopanica, Pure \& Appl. Chem., 61, 97 (1989).

91. C. M. G. Van den Berg, Analyst, 114, 1527 (1989).

92. R. Udisti and G. Piccardi, Fresen. Z. Anal. Chem., 331, 35 (1988).

93. E. D. Moorhead and G. A. Forsberg, Anal. Chem., 48, 751 (1976).

94. P. Cofre and K. Brinck, Talanta, 39, 127 (1992).

95. G. East and P. Cofre, Talanta, 40, 1273 (1993).

96. L'. Medvecký and J. Brianèin, Chem. Pap., 58, 93 (2004).

97. H. S. Sharma, T. K. Bhardwaj, P. C. Jain, and S. K. Aggarwal, Talanta, 71, 1263 (2007).

98. J. Wang and J. M. Zadeii, Anal. Chim. Acta, 185, 229 (1986).

99. M. J. G. González, O. D. Renedo, M. A. A. Lomillo, and M. J. A. Martínem, Talanta, 62, 457 (2004).

100. B. Pihlar, P. Valenta, and H. W. Nürnberg, Fresen. Z.
Anal. Chem., 307, 337 (1981).

101. C. M. G. Van den Berg and Z. Q. Huang, Anal. Chem., 56, 2383 (1984).

102. M. Vega and C.M.G Van den Berg, Anal. Chim. Acta, 293, 19 (1994).

103. J. Wang, B. Tian, and J. Lu, Talanta, 39, 1273 (1992).

104. S. Sander and G. Henze, Fresen. J. Anal. Chem., 356, 259 (1996).

105. L. Qu and W. Jin, Anal. Chim. Acta, 274, 65 (1993).

106. X. Zhang, R. Chen, L. Wang, and C. Ma, Mikrochim. Acta, 118, 213 (1995).

107. R. Piech, Electroanalysis, 21, 1842 (2009).

108. R. Piech, J. Appl. Electrochem., 41, 207 (2011).

109. S. Pysarevska, L. Dubenska, N. Shajnoga, and H. Levytska, Chem. Met. Alloys, 2, 194 (2009).

110. S.K. Mohamed, Anal. Chim. Acta, 562, 204 (2006).

111. A. Abbaspour, S.M. Khoshfetrat, H. Sharghi, and R. Khalifeh, J. hazard. Mater., 185, 101 (2011). 